\title{
Improved activity and stability of chlorobenzene oxidation over transition metal-substituted spinel-type catalysts supported on cordierite
}

Article

Accepted Version

Huang, Q., Xu, G., Zhang, K., Zhu, J., Si, H., Yang, B., Tao, T., Zhao, Y., Chen, M. and Yang, H. ORCID:

https://orcid.org/0000-0001-9940-8273 (2021) Improved activity and stability of chlorobenzene oxidation over transition metal-substituted spinel-type catalysts supported on cordierite. Catalysis Letters, 151. pp. 2313-2325. ISSN 1011-372X doi: https://doi.org/10.1007/s10562-020-03494-4 Available at https://centaur.reading.ac.uk/95942/

It is advisable to refer to the publisher's version if you intend to cite from the work. See Guidance on citing.

To link to this article DOI: http://dx.doi.org/10.1007/s10562-020-03494-4

Publisher: Springer

All outputs in CentAUR are protected by Intellectual Property Rights law, including copyright law. Copyright and IPR is retained by the creators or other copyright holders. Terms and conditions for use of this material are defined in the End User Agreement. 


\section{www.reading.ac.uk/centaur}

\section{CentAUR}

Central Archive at the University of Reading

Reading's research outputs online 


\section{Improved activity and stability of chlorobenzene oxidation over transition metal-substituted spinel-type catalysts supported on cordierite}

Qiong Huang ${ }^{1,}$, Gongda Xu ${ }^{1}$, Kaiqing Zhang ${ }^{2}, \mathrm{Jie} \mathrm{Zhu}^{1}$, Han $\mathrm{Si}^{1}$, Bo Yang ${ }^{1}$, Tao Tao $^{1}$, Yunxia Zhao ${ }^{1}$, Mindong Chen ${ }^{1}$ and Hong Yang ${ }^{1,3, *}$

1 Jiangsu Collaborative Innovation Center of Atmospheric Environment and Equipment Technologies, Jiangsu Key Laboratory of Atmospheric Environmental Monitoring \& Pollution Control, School of Environmental Science \& Engineering, Nanjing University of Information Science \& Technology, Nanjing 210044, China;

${ }^{2}$ Reading Academy, Nanjing University of Information Science \& Technology, Nanjing 210044, China;

3 Department of Geography and Environmental Science, University of Reading, Whiteknights, Reading, RG6 6AB, UK

*Corresponding author 1: Dr. Qiong Huang

School of Environmental Science and Engineering, Nanjing University of Information Science \& Technology, Nanjing 210044, China

Address: No. 219 Ningliu Road, Nanjing University of Information Science \& Technology, School of Environmental Science and Engineering, 210044, Nanjing, China

E-mail: hqhaixia@163.com (Q.H.)

Tel: $+862558731090 \quad$ Fax: +862558731090

*Corresponding author 2: Dr. Hong Yang

Department of Geography and Environmental Science, University of Reading, Whiteknights, Reading, RG6 6AB, UK

E-mail: hongyanghy@gmail.com (H. Y.)

Tel: $+44(0) 1183787750$ 
ABSTRACT: Industrial catalysts usually encounter great challenges in $\mathrm{Cl} \cdot$ deactivation, toxic by-products generation, and stability with a long running operation for catalytic oxidation of chlorinated volatile organic compounds (CVOCs). In this research, spinel-type oxides with transition metal substituted as active oxides supported on cordierite (Crd) was identified to catalytic degradation of chlorobenzene (CB). The $\mathrm{Cu}_{1.4} \mathrm{Mn}_{1.6} \mathrm{O}_{4}$ spinel-type oxides considered as the main active oxides have been identified, which were confirmed by XRD and TEM. The activities of these $\mathrm{CuM}_{\mathrm{x}} \mathrm{Mn}_{2-\mathrm{x}} \mathrm{O}_{4}$ catalysts were markedly improved by lower calcining temperature and shorter time. $\mathrm{CuCe}_{0.25} \mathrm{Mn}_{1.75} \mathrm{O}_{4} / \mathrm{Crd}$ catalyst displayed the highest activity and good stability due to that $\mathrm{CeO}_{2}$ nano-rods structure conducive to increase the $\mathrm{O}_{\text {ads }}$ amount, the dispersion of active oxides, the strength of weak acidity, the surface areas and pore volume. Moreover, spinel-type with $\mathrm{CeO}_{2}$ doping exhibited high performance in CVOCs elimination attributed to the high storage capacity of oxygen, plentiful oxygen vacancies, good efficiency in breaking $\mathrm{C}-\mathrm{Cl}$ bond and the easy shuttles between $\mathrm{Ce}^{3+}$ and $\mathrm{Ce}^{4+}$, which were demonstrated by XPS. The results indicate that $\mathrm{CeO}_{2}, \mathrm{O}_{\text {ads }}$, and $\cdot \mathrm{OH}$ have beneficial effects on the removing $\mathrm{Cl} \cdot$ into benzene, and then improving the ring-opening of $\mathrm{CB}$ for $\mathrm{CB}$ degradation.

Keywords: CVOCs; Catalytic degradation; Spinel-type oxides; Cordierite; Transition metal substitution 


\section{Introduction}

1,2-dichloroethane (DCE), trichloroethylene (TCE), dichloromethane (DCM), chlorobenzene (CB), etc. are important members of CVOCs, which are extensively applied in industry as raw materials or solvents ${ }^{[1,2]}$. In the last decades, CVOCs have received increasing attention due to the damage of these compounds as important atmospheric pollutants to the ecological environment, flora and fauna, and human health ${ }^{[3]}$. Owing to the permanent large toxicity and difficulty in degradation, effective technologies are needed to reduce CVOCs emission ${ }^{[4]}$. Among the methods of CVOCs elimination, catalytic oxidation has emerged as a promising method to degrade CVOCs into relatively less harm gases, for example, $\mathrm{CO}_{2}, \mathrm{H}_{2} \mathrm{O}$ and $\mathrm{HCl}$, attributed to the low energy consumption and the high oxidation efficiency and ${ }^{[5,6]}$. However, the catalytic oxidation has also been constrained by activity, stability, and poisoning ${ }^{[3]}$. In order to improve the activity of CVOCs elimination, some studies have been conducted for three typical catalysts: noble metal, transition metal oxides and zeolites ${ }^{[7,8,9]}$.

Noble metals, for example, $\mathrm{Pt}$ and $\mathrm{Pd}$, have been identified as high activity and effective material for the elimination of VOCs and CVOCs ${ }^{[10]}$. However, due to the high price of precious metals, the $\mathrm{Cl}^{\circ}$ deactivation, and the formation of polychlorinated compounds as by-products are severely limited in industry ${ }^{[11]}$. Meanwhile, these noble metals catalysts could be synthesized with high specific surface areas in order to improve the dispersion of precious metals ${ }^{[12,13]}$.

In recent years, zeolites with abundant acid solid ${ }^{[2,14,15,16]}$ such as H-MOR, H-ZSM5, H-BETA, have received more attention, due to the abundant Brønsted and Lewis acid selected to improve the adsorption and oxidation performance, and resistance to $\mathrm{Cl}$ poisoning. Weng et al ${ }^{[17]}$ indicated that the $\mathrm{Mn}_{0.8} \mathrm{Ce}_{0.2} \mathrm{O}_{2}$ showed deactivation attributed to the accumulation of chloride or coke on the surface of Mn-Ce mixed oxides. While as for the $\mathrm{Mn}_{0.8} \mathrm{Ce}_{0.2} \mathrm{O}_{2} / \mathrm{HZSM}-5$, the process for catalytic oxidation of CB started onto the adsorption of Brønsted acid sites at first, where CB was broke down into phenolates, benzoquinone or cyclohexanone species. Therefore, to some extent, these $\mathrm{Cl}$ or coke could be partially caught by HZSM-5 to defend these active sites. Therefore, the $\mathrm{Mn}_{0.8} \mathrm{Ce}_{0.2} \mathrm{O}_{2} / \mathrm{HZSM}-5$ exhibited the highest activity and stability for $50 \mathrm{~h}$ and the $T_{90}$ was $250{ }^{\circ} \mathrm{C}$ with a WHSV at $15000 \mathrm{~mL} / \mathrm{g}$ in the humid aging condition. Wang et al ${ }^{[18]}$ prepared a series of $\mathrm{Pt}_{\mathrm{x}} \mathrm{Ru}_{\mathrm{y}} / \mathrm{HZSM}-5$ catalysts with different $\mathrm{Pt} / \mathrm{Ru}$ ratios by an improved co-impregnation method and the results indicated that $\mathrm{Pt}$ and $\mathrm{Ru}$ nanoparticles were highly dispersed on hierarchical HZSM-5 supports in form of $\mathrm{Pt}-\mathrm{O}-\mathrm{Ru}$ structures, which improves the reducibility and acidity of the catalysts. The relationship of enhanced redox and acidic properties with close structure-activity for CB oxidation activity were observed.

Dai et al ${ }^{[2]}$ found that $\mathrm{CeO}_{2} @ \mathrm{HZSM}-5$ showed better resistance to the $\mathrm{Cl}$ poisoning and carbon deposition owing to the formed polyaromatic or non-activated coke, which could be eliminated via in situ oxidation by these active oxygen species. The naked HZSM-5 with acid sites can tolerate for the direct adsorption of chlorination and protect $\mathrm{CeO}_{2}$. However, zeolites catalysts are also constrained by two problems: less activity at low temperature ${ }^{[1]}$, and more byproducts of polychlorinated hydrocarbons ${ }^{[6]}$. 
Therefore, much effort has focused on these catalysts synthesized by transition metal oxides, like $\mathrm{V}_{2} \mathrm{O}_{5}, \mathrm{Cr}_{2} \mathrm{O}_{3}, \mathrm{Co}_{3} \mathrm{O}_{4}, \mathrm{MnO}_{2}$, and $\mathrm{NiO}$, by resisting the deactivation to a larger extent ${ }^{[19,20,21,22]}$. However, for some catalysts with one of transition metal oxide, the formation of volatile species at low temperature, such as metal chloride or metal chloride oxide, and even the loss of active sites adsorbing $\mathrm{HCl} / \mathrm{Cl}_{2}$ may lead to partial deactivation, which will constrain its applications in industry ${ }^{[23]}$. According to the synergetic effect on the interactions of metal oxides-metal oxides or metal oxidessupport, composite or mixed metal oxides can enhance the surface acidic sites and significantly promote the mobility of the active oxygen on the surface of catalysts ${ }^{[21]}$. Studies found composite oxides ${ }^{[1,24,25]}$, such as perovskite-type and spinel, and mixed oxides, for example, $\mathrm{MnO}_{\mathrm{x}} / \mathrm{CeO}_{2}{ }^{[26,}{ }^{27]}, \mathrm{VO}_{\mathrm{x}} / \mathrm{CeO}_{2}{ }^{[28]}, \mathrm{SnO}_{\mathrm{x}}-\mathrm{MnO}_{\mathrm{x}}-\mathrm{TiO}_{2}{ }^{\text {[29] }}$, $\mathrm{CeO}_{2} / \mathrm{TiO}_{2}{ }^{[30]}, \mathrm{Cr} / \mathrm{TiO}_{2}{ }^{[31]}$, and others ${ }^{[32]}$, can be replaced by transition metal oxides, according to the lowering of cost, high oxidation activity and thermal stability for CVOCs degradation. According to reports, $\mathrm{CeO}_{2}$ show a high performance in eliminating CVOCs due to the significant effect in breaking the $\mathrm{C}-\mathrm{Cl}$ bond ${ }^{[33,34]}$. But, it is still easy to be inactivated owing to these large amount of $\mathrm{Cl}^{\circ}$ adsorption on the active sites of $\mathrm{CeO}_{2}$.

As the third catalysts of transition metal oxides have received more attention owing to the high activity and good tolerance to $\mathrm{Cl}$ poisoning ${ }^{[29,35]}$. In these transition metal oxides, ceria-based oxides, like $\mathrm{CeO}_{2}-\mathrm{TiO}_{2}{ }^{[6]}, \mathrm{CeO}_{2}-\mathrm{FeO}_{\mathrm{x}}{ }^{[5]}, \mathrm{CeO}_{2}-\mathrm{CrO}_{\mathrm{x}}{ }^{[33,36]}, \mathrm{CeO}_{2}-$ $\mathrm{VO}_{\mathrm{x}}{ }^{[28,37]}, \mathrm{CeO}_{2}-\mathrm{WO}_{\mathrm{x}}{ }^{[3]}$, and $\mathrm{CeO}_{2}-\mathrm{MnO}_{\mathrm{x}}{ }^{[14,26,38]}$, have attracted more attention due to the high oxygen storage capacity, $\mathrm{Ce}^{4+} / \mathrm{Ce}^{3+}$ redox properties of cerium oxide, and the strong interplay between $\mathrm{MO}_{\mathrm{x}}$ and $\mathrm{CeO}_{2}$. Recently, composite oxides as perovskitetype and spinel-type were also identified as feasible catalysts to complete catalytic oxidation of CVOCs ascribed to good thermal stability, good tolerance to chlorine poisoning, high oxygen mobility and relatively higher activities ${ }^{[39]}$. The perovskitetype oxides, such as $\mathrm{LaCoO}_{3}{ }^{[4]}$ and $\mathrm{LaMnO}_{3}{ }^{[40]}$, are the commonest compounds for CVOCs oxidation. In order to further enhance the activities, it is necessary to modify these perovskite-type oxides with other transition metals, especially in the B-site. Zhang et al ${ }^{[41]}$ prepared $\mathrm{LaMnO}_{3}$ with the substitution of B-site, such as $\mathrm{Ni}$, Co, and $\mathrm{Fe}$, for vinyl chloride degradation. The result showed that the activity of $\mathrm{LaMnO}_{3}$ catalysts was significantly impacted by the large amount of adsorbed oxygen species or vacancies and the low-temperature reducibility of the B-site. Higher vinyl chloride degradation could be completed due to B-site substitution, which was related to the large amount of adsorbed oxygen on the surface, the higher oxygen mobility, and the lower reducibility temperature. The catalyst ranking in terms of $\mathrm{O}_{\text {ads }}$ quantity from the highest to the lowest is $\mathrm{LNMO}>\mathrm{LCMO}>\mathrm{LFMO}>\mathrm{LMO}$. So the $\mathrm{LaNi}_{0.2} \mathrm{Mn}_{0.8} \mathrm{O}_{3}$ displayed the best performance $\left(T_{90}=210^{\circ} \mathrm{C}\right)$ for abatement of $1000 \mathrm{ppm}$ of $\mathrm{VC}$ in air at a GHSV of $15000 \mathrm{~h}^{-1}$. Moreover, $\mathrm{LaMnO}_{3}$ can display a preferable performance accompanied by the good stability and durability owing to perovskite-type oxides supported by $\mathrm{Al}_{2} \mathrm{O}_{3}, \mathrm{CeO}_{2}$, and $\mathrm{TiO}_{2}{ }^{[7]}$.

However, so far, spinel-type oxides are rarely studied in depth for catalytic oxidation of CVOCs and the oxidation mechanism has not been explained, clearly. Mn-modified 
$\mathrm{Co}_{3} \mathrm{O}_{4}\left(\mathrm{CoCo}_{2} \mathrm{O}_{4}\right)$ as spinel-type oxides synthesized by co-precipitation had been applied in 1,2-dichlorobenzene oxidation ${ }^{[42]}$. The results showed that the substitute of $\mathrm{Mn}$ for $\mathrm{Co}^{3+}$ at octahedral sites can increase the concentration of $\mathrm{Co}^{2+}$ in the $\mathrm{Co}_{3} \mathrm{O}_{4}$ spinel-type, which involved the binding energy of lattice oxygen $\left(\mathrm{O}^{2-}\right)$. Although the mobility of surface-active oxygen is affected significantly by Mn doping, the catalytic activity of $\mathrm{Mn}_{\mathrm{x}} \mathrm{Co}_{3-\mathrm{x}} \mathrm{O}_{4}$ increases with the $\mathrm{Co}^{2+}$ concentration enhances. The results revealed that the catalyst with $\mathrm{Co} / \mathrm{Mn}$ ratio of nine presented the highest activity with $T_{90}$ of $347^{\circ} \mathrm{C}$ and high stability at least $35 \mathrm{~h}$ at $3000 \mathrm{ppm} o$-DCB and $10 \% \mathrm{O} 2$ at GHSV $=15,000 \mathrm{~h}-1$. The above-mentioned results of transition metal oxides, especially composite oxides, confirm that the performance of oxidation-reduction and the structure are important for catalytic oxidation of CVOCs. In addition, four important aspects should be considered: the performance of spinel-type oxides supported over the carrier, the $\mathrm{Cr}, \mathrm{Co}, \mathrm{Fe}$, and others modified for spinel-type oxides, the surface acidity, and the stability. In general, powder catalyst was difficult to be widely used in industry due to secondary pollution of dust and loss of active components. Therefore, in this work, various transition metal $(\mathrm{M}=\mathrm{Cr}, \mathrm{Co}, \mathrm{Fe}, \mathrm{Ni}$, and $\mathrm{Ce})$ substituted the $\mathrm{B}$ position of spinel oxides supported on Crd as the most widely used carrier for industrial catalyst were prepared. The effects of the content of this transition or rare earth metal oxides, the molar ratio of $\mathrm{M} / \mathrm{Mn}$, surface acidity, calcining temperature and time, and stability on the properties of catalytic oxidation of $\mathrm{CB}$ were investigated.

\section{Experiments}

\subsection{Catalyst preparation}

Spinel-type catalysts with $\mathrm{Cr}, \mathrm{Co}, \mathrm{Fe}, \mathrm{Ni}$ and $\mathrm{Ce}$ substitution supported on Crd were synthesized by the complex method with citric acid. The definite means are as follows: weigh appropriate amount of $\mathrm{Cu}\left(\mathrm{NO}_{3}\right)_{2} \cdot 3 \mathrm{H}_{2} \mathrm{O}$ and $\mathrm{Mn}\left(\mathrm{NO}_{3}\right)_{2}(50.0 \mathrm{wt} \%)$ with the $\mathrm{Cu} / \mathrm{Mn}$ molar ratio at $1: 2$, and then add to $40 \mathrm{ml}$ deionized water with continuous stirring. Then a certain amount of citric acid (1/6 times of total metal ions) and another nitrate (the $\mathrm{M} / \mathrm{Mn}$ molar ratio was at $1 / 3$ ), such as $\mathrm{Fe}\left(\mathrm{NO}_{3}\right)_{3} \cdot 9 \mathrm{H}_{2} \mathrm{O}, \mathrm{Cu}\left(\mathrm{NO}_{3}\right)_{2} \cdot 3 \mathrm{H}_{2} \mathrm{O}$, $\mathrm{Cr}\left(\mathrm{NO}_{3}\right)_{3} \cdot 9 \mathrm{H}_{2} \mathrm{O}, \mathrm{Ni}\left(\mathrm{NO}_{3}\right)_{2} \cdot 6 \mathrm{H}_{2} \mathrm{O}$, and $\mathrm{Ce}\left(\mathrm{NO}_{3}\right)_{3} \cdot 6 \mathrm{H}_{2} \mathrm{O}$, were all added into the solution until completely dissolved. After stirring for $0.5 \mathrm{~h}$, the above solution was heated to $80^{\circ} \mathrm{C}$ until the sol formed. After that, Crd were impregnated into the sol with continuous stirring for $4 \mathrm{~h}$ and then take out with a medicine spoon. Finally, the resulting supported catalysts were dried at $80^{\circ} \mathrm{C}$ for $6 \mathrm{~h}$ and calcined at $450^{\circ} \mathrm{C}$ for $7 \mathrm{~h}$ with $30 \mathrm{wt} \%$ metal oxides loading. For contrast, the other catalysts with different $\mathrm{M} / \mathrm{Mn}$ molar ratio, calcining temperature and time were synthesized with the same method.

\subsection{Characterisation}

Powder X-ray diffraction (XRD) patterns were performed on a diffractometer (D/max$\mathrm{RB}$, Shimadzu XRD-6100) with $\mathrm{Cu} \mathrm{K}_{\alpha}$ radiation $(40 \mathrm{kV}, 150 \mathrm{~mA}, \lambda=0.15406 \mathrm{~nm}$ ). The $2 \theta$ angle was scanned in the $2 \theta$ range of $10-80^{\circ}$ with the scanning rate of $4 \% \mathrm{~min}$. $\mathrm{N}_{2}$ static adsorption-desorption was characterized at $77 \mathrm{~K}$ using a Quantachrome AutosorbiQ-C apparatus. Before the testing, all samples were all pretreatment under vacuum for $4 \mathrm{~h}$ at $300^{\circ} \mathrm{C}$. Brunauer-Emmett-Teller (BET) was used to calculate specific 
surface areas $\left(S_{\mathrm{BET}}\right)$, while Barrett-Joyner-Halenda $(\mathrm{BJH})$ was utilized to calculate average pore diameter $\left(D_{\mathrm{BJH}}\right)$. Scanning electron microscopy (SEM) was operated at $5.0 \mathrm{kV}$ by the Hitachi S-4800 microscope to observe the surface morphologies of these samples. Meanwhile, High resolution transmission electron microscopy (HR-TEM) was conducted on a JEM-2100F operated at an acceleration voltage of $200 \mathrm{kV}$.

$\mathrm{H}_{2}$ Temperature-programmed reduction $\left(\mathrm{H}_{2}\right.$-TPR) was performed on a TP-5080 (Xianquan, Tianjin, China) using a thermal conductivity detector (TCD) equipped with mass spectrometer (MS, INFICON IPC400 quadrupole). In each test, catalysts (50 mg) pretreated in the 5 vol. $\% \mathrm{H}_{2} / \mathrm{N}_{2}(40 \mathrm{~mL} / \mathrm{min})$ from 30 to $450{ }^{\circ} \mathrm{C}$ and maintained at $450{ }^{\circ} \mathrm{C}$ for $1 \mathrm{~h}$. After cooling down, the quartz reactor was heated to $800{ }^{\circ} \mathrm{C}$ at a rate of $15^{\circ} \mathrm{C} / \mathrm{min}$. In the meantime, the $\mathrm{H}_{2}$ consumption was detected by a gas chromatograph equipped with TCD, and the result was calibrated by the $\mathrm{CuO}$ reduction. Temperatureprogrammed desorption of ammonia $\left(\mathrm{NH}_{3}-\mathrm{TPD}\right)$ was performed on the same apparatus as $\mathrm{H}_{2}$-TPR. Typically, catalysts $(100 \mathrm{mg})$ were pretreated at $550^{\circ} \mathrm{C}$ under $50 \mathrm{~mL} / \mathrm{min}$ $\mathrm{N}_{2}$ for $1 \mathrm{~h}$ and then cool down to $50^{\circ} \mathrm{C}$. Then, ammonia was absorbed by introducing a 10 vol.\% $\mathrm{NH}_{3} / \mathrm{N}_{2}$ flow of $50 \mathrm{~mL} / \mathrm{min}$ and kept at $50{ }^{\circ} \mathrm{C}$ until saturation state. And then, to remove the physically adsorbed ammonia, a $\mathrm{N}_{2}$ flow $30 \mathrm{~mL} / \mathrm{min}$ was injected until the stabilization of MS baseline. Finally, signal corresponding to $\mathrm{NH}_{3}$ desorption $(\mathrm{m} / \mathrm{e}=17)$ was collected by TCD from 50 to $550^{\circ} \mathrm{C}$ at a rate of $10^{\circ} \mathrm{C} / \mathrm{min}$ in the $\mathrm{He}$ stream.

The x-ray photoelectron spectroscopy (XPS) spectra of all catalysts were recorded on a Kratos AXIS Ultra spectrometer with a monochromatized Al K $\alpha$ radiation (1486.7 $\mathrm{eV}$ ). The X-ray anode was run at $225 \mathrm{~W}$ and the passing energy was fixed at $20 \mathrm{eV}$. $\mathrm{C} 1 \mathrm{~s}$ of adventitious carbon with at $284.6 \mathrm{eV}$ was used as the reference for binding energy. The infrared spectra (IR, MAGNA-IR750) were scanned at a rate of 32 times/seconds from 4000 to $400 \mathrm{~cm}^{-1}$ to identify these by-products in CB degradation.

\subsection{Activity measurements}

Catalytic degradation of $\mathrm{CB}$ was performed in a continuous-flow fixed-bed reactor, which includes a quartz tube with a diameter of $8 \mathrm{~mm}$ and filled with the $3.0 \mathrm{~g}$ of synthesized catalysts ( $4.8 \mathrm{ml}$ in volume, $5 \sim 12 \mathrm{mesh}$ ) in the quartz tube. The CB contained gas was generated by bubbles form with air through a self-made reactor, and then further diluted with air to maintain the CB concentration at 500ppm. And the air flow was controlled by mass flow controllers to keep the feeding flow rate at 800 $\mathrm{mL} / \mathrm{min}$ and the gas space velocity (GHSV) at $15000 \mathrm{~h}^{-1}$. In each experiment, The CB in outlet gas was analyzed online gas chromatography (Fuli, GC9790II) equipped with a flame ionization detector (FID) with the using of a stainless steel chromatographic column (Restek Rtx-1, $0.25 \mu \mathrm{m} \times 0.25 \mu \mathrm{m} \times 30 \mathrm{~m}$ ). Besides, the reaction temperature was raised to $300{ }^{\circ} \mathrm{C}$ at first with the stabilization $\mathrm{CB}$ concentration for $10 \mathrm{~min}$, and then heat up to $500{ }^{\circ} \mathrm{C}$ by a second temperature ramp of $10{ }^{\circ} \mathrm{C} / \mathrm{min}$. And these conversions calculated by the difference $\mathrm{CB}$ concentration were repeated three times for each time and the averages were calculated.

\section{Results and discussion}




\subsection{X-ray powder diffraction and BET surface area measurements}

The XRD spectra of spinel-type oxides are displayed in Fig. 1. Obvious characteristic diffraction peaks of Crd at $2 \theta=10.4^{\circ}, 21.7^{\circ}, 26.4^{\circ}, 28.4^{\circ}, 29.5^{\circ}$, and $54.2^{\circ}$ (PDF \# 120303) appeared on all the catalysts studied (Fig. 4(A)) ${ }^{[43]}$. However, the intensity of diffraction peaks of $\mathrm{Crd}$ decreased with these spinel oxides supporting ascribed to the covering of metal oxides on the surface of Crd. In the meantime, the catalysts also reveal some small diffraction peaks at $30.4^{\circ}, 35.8^{\circ}, 57.6^{\circ}$, and $63.3^{\circ}$, which are attributed to the $\mathrm{Cu}_{1.4} \mathrm{Mn}_{1.6} \mathrm{O}_{4}$ spinel-type oxides ${ }^{[44]}$. Based on the above results, we can see that the $\mathrm{Cu} / \mathrm{Mn}$ molar ratio was not 1:2, probably due to some of the manganese oxides exited, independently. To investigate the influence of calcining temperature and time on the crystal structure of these catalysts, the wide-angle XRD patterns of spinel catalysts with $\mathrm{Cr}, \mathrm{Fe}$ and $\mathrm{Ce}$ substitution are detected and shown in Fig. 1(B). The support still displayed as Crd crystal, implying that high calcining temperature at $550^{\circ} \mathrm{C}$ did not change the structure of $\mathrm{Crd}$. Regarding spinel catalysts with $\mathrm{CrO}_{\mathrm{x}}$ and $\mathrm{FeO}_{\mathrm{x}}$ substitution, the characteristic peaks for $\mathrm{Cu}_{1.4} \mathrm{Mn}_{1.6} \mathrm{O}_{4}$ spinel-type oxides could be also found in these catalysts. In the meantime, the intensity of $\mathrm{Cu}_{1.4} \mathrm{Mn}_{1.6} \mathrm{O}_{4}$ spinel-type oxides increased with calcining temperature increasing, but the oxidation activity of these two kinds of catalysts decreased. However, for $\mathrm{CuCe}_{0.25} \mathrm{Mn}_{1.75} \mathrm{O}_{4}$ catalysts, these oxides supported on $\mathrm{Crd}$ did not exhibited significant characteristic diffraction peaks for these oxides, such as $\mathrm{MnO}_{\mathrm{x}}, \mathrm{CeO}_{2}$ or $\mathrm{Cu}_{1.4} \mathrm{Mn}_{1.6} \mathrm{O}_{4}$, indicating that these oxides with spinel structure might be highly distributed on the surface of Crd. Therefore, $\mathrm{CuCe}_{\mathrm{x}} \mathrm{Mn}_{2-\mathrm{x}} \mathrm{O}_{4}$ catalysts exhibited higher surface areas and pore volume than other catalysts.

The BET surface areas, pore volume and diameter of spinel catalysts with different $\mathrm{M} / \mathrm{Mn}$ molar ratio $(\mathrm{M}=\mathrm{Cr}, \mathrm{Fe}$, and $\mathrm{Ce})$ are exhibited in Table 1. The pore-size distribution curves and $\mathrm{N}_{2}$ adsorption/desorption isotherms are also showed in Fig. 2. The BET surface areas and pore volume of $\mathrm{CuCe}_{\mathrm{x}} \mathrm{Mn}_{2-\mathrm{x}} \mathrm{O}_{4} / \mathrm{Crd}$ were markedly larger than spinel oxides with $\mathrm{Cr}$ and $\mathrm{Fe}$ substitution. $\mathrm{CuCe}_{\mathrm{x}} \mathrm{Mn}_{2-\mathrm{x}} \mathrm{O}_{4} / \mathrm{Crd}$ with more active sites exhibited higher oxidation activity and better stability than the other catalysts. Moreover, the pore volume and BET surface areas of $\mathrm{CuCe}_{\mathrm{x}} \mathrm{Mn}_{2-\mathrm{x}} \mathrm{O}_{4} / \mathrm{Crd}$ firstly enhanced and then decreased with the $\mathrm{CeO}_{2}$ increasing, but the corresponding activity for $\mathrm{CB}$ oxidation was different from the change rule of BET surface areas. Among of them, the $\mathrm{CuCe}_{0.5} \mathrm{Mn}_{1.5} \mathrm{O}_{4} / \mathrm{Crd}$ showed the largest surface areas, but the activity was lower than $\mathrm{CuCe}_{0.25} \mathrm{Mn}_{1.75} \mathrm{O}_{4} / \mathrm{Crd}$, implying that the BET surface area was not the only factor to change the activity for these catalysts ${ }^{[3]}$. Fig. 5 clearly shows that these catalysts demonstrated a Type III isotherm, indicating that these catalysts display typical mesoporous materials. The hysteresis loop with a relative pressure $\left(P / P_{0}\right)$ from 0.45 to 0.9 showed the existence of irregular mesopores. However, the average pore sizes $(13.7 \mathrm{~nm}, 19.4 \mathrm{~nm}$ and $17.8 \mathrm{~nm})$ of $\mathrm{CuCe}_{\mathrm{x}} \mathrm{Mn}_{2-\mathrm{x}} \mathrm{O}_{4} / \mathrm{Crd}$ catalysts enhanced first and then decreased with the increasing of $\mathrm{CeO}_{2}$. In addition, these catalysts with $\mathrm{CeO}_{2}$ doping exhibited more macroporous structure than other samples, owing to the accumulation of $\mathrm{CeO}_{2}$ primary nanoparticles with a large atomic diameter on the surface. 


\subsection{SEM and TEM characterization}

Scanning electron micrographs of $\mathrm{CuM}_{\mathrm{x}} \mathrm{Mn}_{2-\mathrm{x}} \mathrm{O}_{4} / \mathrm{Crd}(\mathrm{M}=\mathrm{Cr}, \mathrm{Fe}$, and Ce) catalysts are illustrated in Fig. 3. They exhibited different morphological structures and distribution of active oxides on the surface. It was especially noticed that the high activity was closely interrelated with the distribution of these active oxides. The catalysts displayed a high dispersion of active oxides that could demonstrate higher activity for $\mathrm{CB}$ oxidation. $\mathrm{CuCrMnO}_{4} / \mathrm{Crd}$ catalysts (Fig. 3(B)) showed a lot of irregular spherical oxides, which was beneficial to improve the activity for $\mathrm{CB}$ degradation, while the agglomeration effect on compaction and sintering also appeared in the sample of $\mathrm{CuCrMnO}_{4} / \mathrm{Crd}$ (Fig. 3(A)). The same result occurred in the samples of $\mathrm{CuFe}_{x} \mathrm{Mn}_{2-}$ ${ }_{\mathrm{x}} \mathrm{O}_{4} / \mathrm{Crd}$ and $\mathrm{CuCe}_{\mathrm{x}} \mathrm{Mn}_{2-\mathrm{x}} \mathrm{O}_{4} / \mathrm{Crd}$. As displayed in Fig. 3(E), it was excellent to find some of the nano-rods as $\mathrm{CeO}_{2}$ on the surface of $\mathrm{CuCe}_{0.25} \mathrm{Mn}_{1.75} \mathrm{O}_{4} / \mathrm{Crd}$ catalyst ${ }^{[45]}$, which was consistent with TEM. However, it was difficult to find these $\mathrm{CeO}_{2}$ nano-rods in the sample of $\mathrm{CuCeMnO}_{4} / \mathrm{Crd}$.

Fig. 4 shows HRTEM images of $\mathrm{CuM}_{\mathrm{x}} \mathrm{Mn}_{2-\mathrm{x}} \mathrm{O}_{4} / \mathrm{Crd}(\mathrm{M}=\mathrm{Cr}, \mathrm{Fe}$, and $\mathrm{Ce})$ catalysts. The interplanar spacing of $0.251 \mathrm{~nm}$ and $0.439 \mathrm{~nm}$ corresponded to (3 111$)$ and (1 00 ) crystal planes of $\mathrm{Cu}_{1.4} \mathrm{Mn}_{1.6} \mathrm{O}_{4}$ and $\mathrm{MnO}$, which was good agreement with XRD. The size of observed $\mathrm{Cu}_{1.4} \mathrm{Mn}_{1.6} \mathrm{O}_{4}$ and $\mathrm{MnO}$ particles were about in the range of 6-10nm. The result demonstrates that not all of the manganese oxides would combine with copper oxides to form spinel complex oxides, indicating that these oxides existed in the form of mixed oxides. With the presence of $\mathrm{CrO}_{\mathrm{x}}$ and $\mathrm{FeO}_{\mathrm{x}}$, no evident crystal planes of $\mathrm{CrO}_{\mathrm{x}}$ and $\mathrm{FeO}_{\mathrm{x}}$ and changing in morphology were observed. Except for $\mathrm{Cu}_{1.4} \mathrm{Mn}_{1.6} \mathrm{O}_{4}$ in the samples of $\mathrm{CuCe}_{0.25} \mathrm{Mn}_{1.75} \mathrm{O}_{4} / \mathrm{Crd}$, it can also be observed that the (2 2 2) crystal planes of $\mathrm{CeO}_{2-\mathrm{x}}$ showed plentiful oxygen vacancies with a nano-rods structure, with the length at $56 \mathrm{~nm}$ and width at $18 \mathrm{~nm}$. This result displayed the strong interplay between $\mathrm{Cu}_{1.4} \mathrm{Mn}_{1.6} \mathrm{O}_{4}$ and $\mathrm{CeO}_{2-x}$ with the rising oxygen transfer in the $\mathrm{CuCe}_{0.25} \mathrm{Mn}_{1.75} \mathrm{O}_{4} / \mathrm{Crd}$ catalysts.

\section{$3.3 \mathrm{H}_{2}-\mathrm{TPR}$ and $\mathrm{NH}_{3}-\mathrm{TPD}$ measurements}

The $\mathrm{H}_{2}$-TPR and $\mathrm{NH}_{3}$-TPD measurements illustrated in Fig. 5 are used to investigate the reducibility within $100-800^{\circ} \mathrm{C}$ (Fig. 5(A)) and surface acid properties (Fig. 5(B)) of $\mathrm{CuM}_{0.5} \mathrm{Mn}_{1.5} \mathrm{O}_{4} / \mathrm{Crd}(\mathrm{M}=\mathrm{Cr}, \mathrm{Co}, \mathrm{Fe}, \mathrm{Ni}$, and $\mathrm{Ce})$. The profiles were similar to those observed for $\mathrm{Cu}_{1.4} \mathrm{Mn}_{1.6} \mathrm{O}_{4}$ composite oxides where two peaks presented, the first reduction peak at low temperature and the second intense and broad multi-composite peak at high temperature ${ }^{[46]}$. Although, it was difficult to impute the each peak to concrete redox species, according to previous reports ${ }^{[46]}$, the two-step reduction indicated that the two cationic components of $\mathrm{Cu}_{1.4} \mathrm{Mn}_{1.6} \mathrm{O}_{4}$ could be restored to $\mathrm{Cu}^{0}$ and $\mathrm{Mn}^{2+}$. Therefore, it could be inferred that the peak at low temperature (197-226 $\left.{ }^{\circ} \mathrm{C}\right)$ ascribed to the $\mathrm{Cu}^{2+}$ reduction and the peak at high temperature $\left(273-420^{\circ} \mathrm{C}\right.$ ) corresponded to the $\mathrm{Mn}^{4+}$ and $\mathrm{Mn}^{3+}$ reduction. The manganese oxide displayed two $\mathrm{H}_{2}$ reduction peaks; and the first $\left(273^{\circ} \mathrm{C}, 312^{\circ} \mathrm{C}, 324^{\circ} \mathrm{C}, 338^{\circ} \mathrm{C}\right.$ and $\left.359^{\circ} \mathrm{C}\right)$ and the second $\left(278^{\circ} \mathrm{C}, 333^{\circ} \mathrm{C}, 377^{\circ} \mathrm{C}\right.$ and $\left.420^{\circ} \mathrm{C}\right)$ were attributed to the reducibility of $\mathrm{Mn}^{4+}$ to $\mathrm{Mn}^{3+}$ and $\mathrm{Mn}^{3+}$ to $\mathrm{Mn}^{2+}$ in these samples of $\mathrm{CuM}_{0.5} \mathrm{Mn}_{1.5} \mathrm{O}_{4} / \mathrm{Crd}(\mathrm{M}=\mathrm{Cr}, \mathrm{Co}, \mathrm{Fe}, \mathrm{Ni}$, and Ce), respectively. The extra peak at about $580^{\circ} \mathrm{C}$ was probably attributed to the reduction of 
$\mathrm{Ni}^{3+}$ to $\mathrm{Ni}^{2+}{ }^{[47]}$. The above results illustrated that the different metal oxides doping would have a far-reaching influence on the redox properties. Among these catalysts, $\mathrm{CuFe}_{0.5} \mathrm{Mn}_{1.5} \mathrm{O}_{4} / \mathrm{Crd}$ was the most reducible. The strong interplay between $\mathrm{FeO}_{\mathrm{x}}$ and $\mathrm{MnO}_{\mathrm{x}}$ can improve the mobility of active oxygen species and it was conducive to further decompose these intermediate reactants and byproducts formed for $\mathrm{CB}$ oxidation. In terms of $\mathrm{CuCe}_{0.5} \mathrm{Mn}_{1.5} \mathrm{O}_{4} / \mathrm{Crd}$, the $\mathrm{H}_{2}$ consumption was markedly lower than other catalysts with $\mathrm{Ni}$ and Co oxides doping, suggesting that an amount of cerium oxides hindered the reduction of $\mathrm{MnO}_{\mathrm{x}}$ on the surface. However, ceria oxides displayed a better performance in CVOCs decomposition, attributed to the high oxygen storage capacity, plentiful oxygen vacancies, effect in breaking $\mathrm{C}-\mathrm{Cl}$ bond and the easy shuttles between $\mathrm{Ce}^{3+}$ and $\mathrm{Ce}^{4+}[48]$.

Accumulating evidences have reported that acid site was a significant role in the CVOCs elimination, so the $\mathrm{NH}_{3}$-TPD of $\mathrm{CuM}_{0.5} \mathrm{Mn}_{1.5} \mathrm{O}_{4} / \mathrm{Crd}(\mathrm{M}=\mathrm{Cr}, \mathrm{Co}, \mathrm{Fe}, \mathrm{Ni}$, and Ce) catalysts are analyzed and shown in Fig. 8(B). For the $\mathrm{CuCr}_{0.5} \mathrm{Mn}_{1.5} \mathrm{O}_{4} / \mathrm{Crd}$, it indicated two strong $\mathrm{NH}_{3}$ desorption peaks appeared at about $290^{\circ} \mathrm{C}$ and $460^{\circ} \mathrm{C}$. The two peaks at low and high temperature assigned to the weak and strong acid sites, respectively ${ }^{[6,36]}$. For other catalysts, only one of $\mathrm{NH}_{3}$ desorption peak located at low temperature can be found, indicating that the strength of strong acidity was evidently improved according to the $\mathrm{CrO}_{\mathrm{x}}$ doping over $\mathrm{CuCr}_{0.5} \mathrm{Mn}_{1.5} \mathrm{O}_{4} / \mathrm{Crd}$. Among these catalysts, the $\mathrm{CuM}_{0.5} \mathrm{Mn}_{1.5} \mathrm{O}_{4} / \mathrm{Crd}$ with $\mathrm{Ni}$ and $\mathrm{Ce}$ oxides doping exhibited the strongest and the weakest strength of weak acidity, showing the worst and best activities for CB oxidation. The results indicate that it was a disadvantage for catalytic oxidation of $\mathrm{CB}$ over the $\mathrm{CuM}_{0.5} \mathrm{Mn}_{1.5} \mathrm{O}_{4} / \mathrm{Crd}$ catalyst with a strong strength of weak acidity, while it had little effect for CB oxidation over the catalyst with the strong acidity.

\subsection{XPS analysis}

XPS is an efficient technique to investigate the chemical states and surface compositions of these catalysts. The corresponding spectra of $\mathrm{Ce} 3 \mathrm{~d}, \mathrm{Cu} 2 \mathrm{p}, \mathrm{Mn} 2 \mathrm{p}$ and $\mathrm{O} 1 \mathrm{~s}$ of as-prepared catalysts are illustrated in Fig. 6. The ratios of $\mathrm{O}_{\text {latt }} / \mathrm{O}_{\text {ads }}$ and $\mathrm{Ce}^{3+} / \mathrm{Ce}^{4+}$ are encapsulated in Table 1 . According to previous studies ${ }^{[46,49]}$, Ce $3 \mathrm{~d}_{5 / 2}$ and $\mathrm{Ce} 3 \mathrm{~d}_{3 / 2}$ doublets were connected with four pairs of spin-orbit doublets and denoted as $\mathrm{v}$ and $\mathrm{u}$, assigned to deconvolution into eight peaks marked as $\mathrm{u}\left(\mathrm{u}, \mathrm{u}\right.$ ', $\mathrm{u}^{\prime}$ ', $\mathrm{u}^{\prime \prime}$ ') for $3 d_{3 / 2}$ and $v\left(v, v ', v ', v\right.$ "') for $3 d_{5 / 2}$. In all peaks, six peaks denoted as $v(u), v$ ' '(u') and $v^{\prime \prime}$ ' (u', ') were assigned to $\mathrm{Ce}^{4+}$, whereas the other peaks of $v^{\prime}$ and $\mathrm{u}^{\prime}$ attributed to $\mathrm{Ce}^{3+}$. Based on the contribution of $\mathrm{Ce}^{3+}$ features to the spectrum, the ratios of $\mathrm{Ce}^{3+} / \mathrm{Ce}^{4+}$ of $\mathrm{CuCe}_{\mathrm{x}} \mathrm{Mn}_{1-\mathrm{x}} \mathrm{O}_{4} / \mathrm{Crd}$ catalysts with the $\mathrm{Ce} / \mathrm{Mn}$ molar ratios at 1/7, 1/3, 1 and the calcining temperature at $350^{\circ} \mathrm{C}, 450^{\circ} \mathrm{C}, 550^{\circ} \mathrm{C}$ for 4 h were $31.0 \%, 25.8 \%, 26.4 \%, 25.0 \%, 25.2 \%$ and $24.2 \%$, respectively. The highest $\mathrm{Ce}^{3+}$ content created more oxygen vacancies in $\mathrm{CuCe}_{0.25} \mathrm{Mn}_{1.75} \mathrm{O}_{4} / \mathrm{Crd}$, probably owing to the strong interplay between $\mathrm{Ce}$ and $\mathrm{Mn}^{[50]}$. Simultaneously, these oxygen vacancies were identified as active centers, this is due to theses oxygen in the defective oxides devotes to be transferred and released. While accompanied by the increasing of $\mathrm{CeO}_{2}$ doping, a large amount of cerium oxides exhibited as $\mathrm{CeO}_{2}$ could be found. Although the $\mathrm{Ce}^{3+}$ content significantly increased, the $\mathrm{Ce}^{3+} / \mathrm{Ce}^{4+}$ ratio decreased with the increase of $\mathrm{CeO}_{2}$. Base on the above results, it 
could also be deduced that the ratio of $\mathrm{Ce}^{3+} / \mathrm{Ce}^{4+}$ didn't change with calcining temperature increasing.

Regarding $\mathrm{Cu} 2 \mathrm{p}_{2 / 3}$, one peak, which can be ascribed to $\mathrm{Cu}^{2+}$ at $933.7 \mathrm{eV}$, can be found. The satellite peaks located at $941.3-943.7 \mathrm{eV}$ attributed to $\mathrm{Cu}^{2+}$ on the account of unfilled $3 \mathrm{~d}$ shells. As shown in Fig. 6(B), according to the peak fitting deconvolution of $\mathrm{Cu} 2 \mathrm{p}_{2 / 3}$, two peaks were accessed. The results revealed that the chemical state of $\mathrm{CuO}$ would not transform with the variation of $\mathrm{CeO}_{2}$ doping and calcining temperature.

The binding energy of $\mathrm{Mn} 2 \mathrm{p}_{3 / 2}$ located at $641.5 \mathrm{eV}$ was assigned to $\mathrm{Mn}^{3+}\left(\mathrm{Mn}^{2+}\right)$, which was difficult to discriminate owing to the small distinction in the values of binding energy between $\mathrm{Mn}^{3+}$ and $\mathrm{Mn}^{2+}$, whereas the $\mathrm{Mn} 2 \mathrm{p}_{3 / 2}$ at $642.9 \mathrm{eV}$ was ascribed to $\mathrm{Mn}^{4+}$ [46]. As for $\mathrm{CuCe}_{0.25} \mathrm{Mn}_{1.75} \mathrm{O}_{4} / \mathrm{Crd}$ catalysts with different $\mathrm{Ce} / \mathrm{Mn}$ molar ratios, the $\mathrm{Mn}^{4+} /\left(\mathrm{Mn}^{3+}+\mathrm{Mn}^{2+}\right)$ ratio increased at first and then decreased, indicating the strong interplay between $\mathrm{Mn}$ and Ce. Meanwhile, with the calcining temperature increasing, the $\mathrm{Mn}^{4+} /\left(\mathrm{Mn}^{3+}+\mathrm{Mn}^{2+}\right)$ ratios dramatically increased $(71.9 \%, 74.4 \%$, and $96.5 \%)$ due to the oxidization of $\mathrm{Mn}^{3+}$ to $\mathrm{Mn}^{4+}$, which was disadvantage to improve the activity for $\mathrm{CB}$ degradation. According to the above results, the existence of $\mathrm{Mn}^{4+}$ species was crucial for $\mathrm{Cu}_{1.4} \mathrm{Mn}_{1.6} \mathrm{O}_{4}$, which might be attributable to the redox equilibrium of $\mathrm{Mn}^{3+} / \mathrm{Cu}^{2+}$. Whereas, the calcining temperature at which the spinel catalysts synthesized would have a profound impact on the extent of electron transfer between $\mathrm{Cu}$ and $\mathrm{Mn}$.

The asymmetrical $\mathrm{O} 1 \mathrm{~s}$ spectra could be deconvoluted as two peaks at $529.4 \mathrm{eV}$ assigned to surface lattice oxygen $\left(\mathrm{O}_{\text {latt }}\right)$ and at binding energy of $532.4 \mathrm{eV}$ ascribed to surface adsorbed oxygen $\left(\mathrm{O}_{\mathrm{ads}}, \mathrm{O}^{-}, \mathrm{O}^{2-}\right.$ or $\left.\mathrm{O}_{2}{ }^{2-}\right)$. According to published results ${ }^{[45,51]}$, the $\mathrm{O}_{\text {ads }} / \mathrm{O}_{\text {latt }}$ ratios acquired from the XPS measurements were all less than 1, indicating that the most of oxygen recognized as lattice oxygen on the surface of these catalysts. However, for $\mathrm{CuCe}_{\mathrm{x}} \mathrm{Mn}_{1-\mathrm{x}} \mathrm{O}_{4} / \mathrm{Crd}$ catalysts with good activities at low reaction temperature for $\mathrm{CB}$ oxidation, the amount of $\mathrm{O}_{\text {latt }}$ was considerably lower than $\mathrm{O}_{\text {ads }}$ and the $\mathrm{O}_{\text {latt }} / \mathrm{O}_{\text {ads }}$ ratios were $32.0 \%, 29.5 \%, 29.5 \%, 28.3 \%, 21.1 \%$, and $19.9 \%$, separately. The above results suggested that the potential important role of $\mathrm{O}_{\text {ads }}$ in the good oxidation at low temperatures. With the Ce increasing, the binding energy of $\mathrm{O}_{\text {ads }}$ transferred to low energy, illustrating the marked change of electron cloud density of $\mathrm{O}_{\text {ads }}$ in the electron-transfer process. Along with the increase in calcining temperature, however, the contents of $\mathrm{O}_{\text {ads }}$ increased and the $\mathrm{O}_{\text {latt }}$ decreased with a clear reduction in catalytic activities.

\subsection{Catalytic degradation of $C B$}

The performances of spinel oxides with $\mathrm{Cr}, \mathrm{Co}, \mathrm{Mn}, \mathrm{Fe}, \mathrm{Ni}, \mathrm{Cu}$, or $\mathrm{Ce}$ substitution supported on Crd for CB oxidation are illustrated in Fig. 7. Crd supporter didn't exhibit any activity for catalytic oxidation of $\mathrm{CB}$, even the reaction temperature up to $500^{\circ} \mathrm{C}$ (Fig. 7(A)). When Crd was supported with spinel-type oxides, the catalysts displayed high activity for catalytic oxidation of $\mathrm{CB}$, and $\mathrm{CB}$ can be completely decomposed with the calcination temperature of $450^{\circ} \mathrm{C}$. However, $T_{90}$ was also much higher than noble metal-based, such as $\mathrm{Ru} / \mathrm{TiO}_{2}$ and $\mathrm{Pt} / \mathrm{TiO}_{2}{ }^{[10]}$, Ce-Mn oxides ${ }^{[45]}$, and $\mathrm{VO}_{\mathrm{x}} / \mathrm{CeO}_{2}$ 
catalysts ${ }^{[28]}$. In order to improve the activity over spinel catalysts, five different kinds of transition and rare earth metal oxides including $\mathrm{CrO}_{\mathrm{x}}, \mathrm{CoO}_{\mathrm{x}}, \mathrm{FeO}_{\mathrm{x}}, \mathrm{NiO}$ and $\mathrm{CeO}_{2}$, substituted the B-site of spinel oxides supported on Crd were prepared. The result exhibited that the activity of $\mathrm{CB}$ oxidation was all improved and $T_{90}$ decreased from $450^{\circ} \mathrm{C}$ to $400^{\circ} \mathrm{C}$, especially for $\mathrm{CuCr}_{0.5} \mathrm{Mn}_{1.5} \mathrm{O}_{4} / \mathrm{Crd}, \mathrm{CuFe}_{0.5} \mathrm{Mn}_{1.5} \mathrm{O}_{4} / \mathrm{Crd}$, and $\mathrm{CuCe}_{0.5} \mathrm{Mn}_{1.5} \mathrm{O}_{4} / \mathrm{Crd}$ catalysts. But the $\mathrm{CuNi}_{0.5} \mathrm{Mn}_{1.5} \mathrm{O}_{4} / \mathrm{Crd}$ catalysts showed lower activity than $\mathrm{CuMn}_{2} \mathrm{O}_{4} / \mathrm{Crd}$ at the same reaction temperature. To study and analyze the effect of the molar ratio of $\mathrm{M}(\mathrm{M}=\mathrm{Cr}, \mathrm{Fe}$ and $\mathrm{Ce}) / \mathrm{Mn}$ on catalytic activity, the activity of $\mathrm{CuCr}_{\mathrm{x}} \mathrm{Mn}_{2-\mathrm{x}} \mathrm{O}_{4} / \mathrm{Crd}, \mathrm{CuFe}_{\mathrm{x}} \mathrm{Mn}_{2-\mathrm{x}} \mathrm{O}_{4} / \mathrm{Crd}$ and $\mathrm{CuCe}_{\mathrm{x}} \mathrm{Mn}_{2-\mathrm{x}} \mathrm{O}_{4} / \mathrm{Crd}$ with $\mathrm{x}=0.25,0.5$ and 1 were illustrated in Fig. 7(B). With the increase of $x$ value, the performance of these three kinds of catalysts was different. Compared with the other catalysts, $\mathrm{CuCrMnO}_{4}$, $\mathrm{CuFe}_{0.25} \mathrm{Mn}_{1.75} \mathrm{O}_{4}$, and $\mathrm{CuCe}_{0.25} \mathrm{Mn}_{1.75} \mathrm{O}_{4}$ catalysts exhibited better activities for $\mathrm{CB}$ degradation, thus, the effects of calcining temperature and time were further investigated and the light-off curves were described in Fig. 8.

These three kinds of catalysts $\left(\mathrm{CuCrMnO}_{4}, \mathrm{CuFe}_{0.25} \mathrm{Mn}_{1.75} \mathrm{O}_{4}\right.$, and $\left.\mathrm{CuCe}_{0.25} \mathrm{Mn}_{1.75} \mathrm{O}_{4}\right)$ were all displayed increasing activity for $\mathrm{CB}$ degradation with the reduction of calcining temperature and time. The order of oxidation activity was $550^{\circ} \mathrm{C}, 7 \mathrm{~h}<450^{\circ} \mathrm{C}$, $7 \mathrm{~h}<550^{\circ} \mathrm{C}, 4 \mathrm{~h}<350^{\circ} \mathrm{C}, 7 \mathrm{~h} \approx 450^{\circ} \mathrm{C}, 4 \mathrm{~h} \approx 350^{\circ} \mathrm{C}, 4 \mathrm{~h}$ (Fig. 8). The results demonstrated that the activities could be significant improvement, with low calcining temperature and a short calcining time. The formation of $\mathrm{Cu}_{1.4} \mathrm{Mn}_{1.6} \mathrm{O}_{4}$ spinel-type oxides was consistent with XRD results. $T_{90}$ could decrease to $300^{\circ} \mathrm{C}$, even a lower reaction temperature. $T_{90}$ was also significantly lower than some other catalysts, even some noble metal-based catalysts, such as $\mathrm{Pd} / \mathrm{LaBO}_{3}(\mathrm{~B}=\mathrm{Co}, \mathrm{Mn}, \mathrm{Fe})^{[20]}, \mathrm{VO}_{\mathrm{x}} / \mathrm{CeO}_{2}{ }^{[28]}, \mathrm{Mn}$ $\mathrm{Ce}-\mathrm{O} / \gamma-\mathrm{Al}_{2} \mathrm{O}_{3}{ }^{[38]}$, and_Ce-Mn oxides catalysts ${ }^{[45]}$. These catalysts with a calcining temperature exhibited excellent activity for $\mathrm{CB}$ oxidation.

These three catalysts calcinated at $450^{\circ} \mathrm{C}$ and for $4 \mathrm{~h}\left(\mathrm{CuCrMnO}_{4}, \mathrm{CuFe}_{0.25} \mathrm{Mn}_{1.75} \mathrm{O}_{4}\right.$, and $\mathrm{CuCe}_{0.25} \mathrm{Mnn}_{1.75} \mathrm{O}_{4}$ ) had the best stabilities. Fig. 9 showed that the reaction temperature at $300^{\circ} \mathrm{C}$ played a crucial performance with the high activities. All these catalysts displayed good stability for $\mathrm{CB}$ oxidation at $24 \mathrm{~h}$. Among them, the $\mathrm{CuCe}_{0.25} \mathrm{Mn}_{1.75} \mathrm{O}_{4}$ catalysts demonstrated the best results of activity, stability, and antipoisoning, while the $\mathrm{CuFe}_{0.25} \mathrm{Mn}_{1.75} \mathrm{O}_{4}$ showed a slight decrease in activity with the increase in time.

\subsection{IR analysis}

To analyze the effect of the $\mathrm{CB}$ adsorption and reaction behaviors over spinel catalysts on the different conversions of CB $\left(T_{20}, T_{50}\right.$, and $\left.T_{90}\right)$, IR measurement was applied to check the products of the reaction (Fig.10). According to the previous findings ${ }^{[38,45,52 \text {, }}$ ${ }^{53]}$, the bands at $3427 \mathrm{~cm}^{-1}$ was assigned to the $\mathrm{O}-\mathrm{H}\left(v_{\mathrm{O}-\mathrm{H}}\right)$ stretching vibration, which were adsorbed on the catalysts surface, whereas the bands at $1619 \mathrm{~cm}^{-1}$ corresponded Fig. 10 to the absorbed $\mathrm{O}-\mathrm{H}\left(v_{\mathrm{O}-\mathrm{H}}\right)$ bending vibration. It was worth noting that the performance of water absorption over catalysts, which was beneficial to eliminate the $\mathrm{HCl}$ or $\mathrm{Cl}_{2}$ adsorbed on the surface catalysts, was maintained as the reaction temperature increasing and CB degradation. In the meantime, the bands located at 1830 and 1700 $\mathrm{cm}^{-1}$ were the corresponded to vibration as aldehyde-type and the bands located at 1520 
$\mathrm{cm}^{-1}$ assigned to the ring stretching of benzene. While, the bands at $2345 \mathrm{~cm}^{-1}$ were ascribed to the $\mathrm{CO}_{2}$ vibration and the bands located at 2923 and $2853 \mathrm{~cm}^{-1}$ were originated from the methylene $\left(-\mathrm{CH}_{2}\right)$ asymmetric stretching or $\mathrm{C}-\mathrm{H}$ symmetric. Base on the measurement of IR in the current study and previous studies ${ }^{[14]}$, the $\mathrm{CB}$ oxidation routes over $\mathrm{CuM}_{\mathrm{x}} \mathrm{Mn}_{1-\mathrm{x}} \mathrm{O}_{4} / \mathrm{Crd}$ are proposed as Fig. 11. The presence or formation of $\mathrm{H}_{2} \mathrm{O}$ accelerated $\mathrm{CB}$ ring-opening and exhibited positively effect on $\mathrm{CB}$ degradation, probably attributed to the accumulated $\mathrm{Cl} \cdot$ removal from the surface active oxides, such as $\mathrm{MnO}_{\mathrm{x}}$ or $\mathrm{CeO}_{2}{ }^{[54]}$. According to the presence of benzene in these catalysts, the degradation process of $\mathrm{CB}$ was originated from dechlorination and the formation of benzene at first. And then, benzene was further oxidized into $\mathrm{CO}_{2}$ and $\mathrm{H}_{2} \mathrm{O}$ through a series of processes with these active adsorbed oxygen or lattice oxygen. In this process, $\cdot \mathrm{OH}$ showed the characteristic bands at $1700 \mathrm{~cm}^{-1}$ and had a beneficial effect on the aldehyde-type forming, which were all detected over these catalysts, even at $T_{20}$. Therefore, it was desirable that the $\cdot \mathrm{OH}$ radical had involved in the $\mathrm{CB}$ oxidation, resulting in the significant increase of $\mathrm{CO}_{2}$ over these catalysts.

\section{Conclusions}

The performance of catalytic oxidation of $\mathrm{CB}$ over $\mathrm{CuM}_{\mathrm{x}} \mathrm{Mn}_{2-\mathrm{x}} \mathrm{O}_{4}(\mathrm{M}=\mathrm{Cr}, \mathrm{Co}, \mathrm{Fe}, \mathrm{Ni}$, and $\mathrm{Ce}$ ) catalysts with different activity and stability were reported in this study. The results of XRD and TEM measurements showed that the $\mathrm{Cu}_{1.4} \mathrm{Mn}_{1.6} \mathrm{O}_{4}$ spinel-type oxides could be detected, which displayed a significant role in $\mathrm{CB}$ degradation. $\mathrm{CuCe}_{0.25} \mathrm{Mn}_{1.75} \mathrm{O}_{4} / \mathrm{Crd}$ catalyst with $\mathrm{CeO}_{2}$ nano-rods structure is conducive to improve the $\mathrm{O}_{\text {ads }}$ amount, the distribution of active oxides, the weak acid strength, and pore volume and surface area, so it exhibited higher activity and better stability than other catalysts. Although $\mathrm{H}_{2}$ consumption of $\mathrm{CuCe}_{\mathrm{x}} \mathrm{Mn}_{1-\mathrm{x}} \mathrm{O}_{4} / \mathrm{Crd}$ was markedly lower than other catalysts, ceria oxides displayed a high performance in CVOCs elimination. Ceria oxides have attracted more attention, attributed to the high oxygen storage capacity, plentiful oxygen vacancy, effect in breaking $\mathrm{C}-\mathrm{Cl}$ bond and the easy shuttles with $\mathrm{Ce}^{4+}$ and $\mathrm{Ce}^{3+}$. Meanwhile, the mechanism of $\mathrm{CB}$ oxidation process over $\mathrm{CuM}_{\mathrm{x}} \mathrm{Mn}_{1-\mathrm{x}} \mathrm{O}_{4} / \mathrm{Crd}$ catalysts was discussed and the IR results indicated that $\mathrm{CeO}_{2}, \mathrm{O}_{\text {ads }}$, and $\cdot \mathrm{OH}$ played beneficial effects on the original $\mathrm{Cl}$ - dissociation at first, and then ring-opening to form a variety of products, such as aldehyde-type, alkane, $\mathrm{CO}_{2}$ and so on. Overall, our results provide meaningful solutions to prepare and design spinel-type catalysts for CVOCs degradation.

\section{Acknowledgments}

The authors would like to acknowledge the Natural Science Foundation of Jiangsu Province (No. BK20170954 and BK20150890), the National Natural Science Foundation of China (No. 21501097), the Qing Lan Project of the Jiangsu Higher Education Institutions of China. As well as the projected funded by the Priority Academic Program Development of Jiangsu Higher Education Institutions (PAPD). 


\section{Funding:}

The Natural Science Foundation of Jiangsu Province (No. BK20170954 and No. BK 20150890); The National Natural Science Foundation of China (Nos. 21501097).

\section{References}

[1] S.X. Chen, Y. Wang, A.P. Jia, H.H. Liu, M.F. Luo, J.Q. Lu. Appl. Surf. Sci. 307 (2014) 178-188.

[2] Q.G. Dai, W. Wang, X.Y. Wang, G.Z. Lu. Appl. Catal. B.: Environ. 203 (2017) 3142.

[3] Y.F. Gu, T. Cai, X.H. Gao, H.Q. Xia, W. Sun, J. Zhao, Q.G. Dai, X.Y. Wang. Appl. Catal. B.: Environ. 248 (2019) 264-276.

[4] M.J. Tian, C. He, Y.K. Yu, H. Pan, L. Smith, Z.Y. Jiang, N.B. Gao, Y.F. Jian, Z.P. Hao, Q. Zhu. Appl. Catal. A.: General. 553 (2018) 1-14.

[5] W. Wang, Q. Zhu, Q.G. Dai, X.Y. Wang. Chem. Eng. J. 307 (2017) 1037-1046.

[6] Z.N. Shi, P. Yang, F. Tao, R.X. Zhou. Chem. Eng. J. 295 (2016) 99-108.

[7] C.H. Zhang, C. Wang, S. Gil, A. Boreave, L. Retailleau, Y.L. Guo, J.L. Valverde, A. Giroir-Fendler. Appl. Catal. B.: Environ. 201 (2017) 552-560.

[8] C.C. Du, S.Y. Lu, Q.L. Wang, A.G. Buekens, M.J. Ni, D.P. Debecker. Chem. Eng. J. 334 (2018) 519-544.

[9] W. Tian, X.Y. Fan, H.S. Yang, X.B. Zhang. J. Hazard. Mater. 177 (2010) 887-891.

[10] X.L. Liu, L. Chen, T.Y. Zhu, R.L. Ning. J. Hazard. Mater. 363 (2019) 90-98.

[11] N. Ye, Y. Li, Z. Yang, J. Zheng, S.F. Zuo. Appl. Catal. A.: General. 579 (2019) $44-51$.

[12] S. Zhao, K.Z. Li, S. Jiang, J.H. Li. Appl. Catal. B.: Environ. 181 (2016) 236-248.

[13] X.R. Fu, Y. Liu, W.Y. Yao, Z.B. Wu. Catal. Commun. 83 (2016) 22-26.

[14] P.F. Sun, W.L. Wang, X.X. Dai, X.L. Weng, Z.B. Wu. Appl. Catal. B.: Environ. 198 (2016) 389-397.

[15] A. Aranzabal, J.A. González-Marcos, M. Romero-Sáez, J.R. González-Velasco, M. Guillemot, P. Magnoux. Appl. Catal. B.: Environ. 88 (2009) 533-541.

[16] M.J. Tian, M.D. Ma, B.T. Xu, C.W. Chen, C. He, Z.P. Hao, R. Albilali. Catal. Sci. Technol. 8 (2018) 4503-4514.

[17] X.L. Weng, P.F. Sun, Y. Long, Q.J. Meng, Z.B. Wu. Environ. Sci. Technol. 51 (2017) 8057-8066.

[18] Y. Wang, Y. Chen, L. Zhang, G. Wang, W. Deng, L.M. Guo. Micropor.

Mesopor. Mat. 308 (2020) 110538-110548.

[19] M. Wu, X.Y. Wang, Q.G. Dai, D. Li. Catal. Commun. 11 (2010) 1022-1025. 
[20] H.F. Li, G.Z. Lu, Q.G. Dai, Y.Q. Wang, Y. Guo, Y.L. Guo. Appl. Catal. B.: Environ.102 (2011) 475-483.

[21] Y. Wang, K.S. Liu, J. Wu, Z.M. Hu, L.M. Guo. ACS Catal. 10 (2020) 1002110031

[22] C. He, Y.K. Yu, Q. Shen, J.S. Chen, N.L. Qiao. Appl. Surf. Sci. 297 (2014) 59-69.

[23] Z. Cheng, J.R. Li, P. Yang, S.F. Zuo. Chinese. J. Catal. 39 (2018) 849-856.

[24] Y.J. Lu, Q.G. Dai, X.Y. Wang. Catal. Commun. 54 (2014) 114-117.

[25] J.M. Giraudon, A. Elhachimi, G. Leclercq. Appl. Catal. B.: Environ. 84 (2008) 251-261.

[26] P. Zhao, C.N. Wang, F. He, S.T. Liu. RSC. Adv, 4 (2014) 45665-45672.

[27] L.Y. Wu, F. He, J.Q. Luo, S.T. Liu. RSC. Adv, 7 (2017) 26952-26959.

[28] H. Huang, Y.F. Gu, J. Zhao, X.Y. Wang. J. Catal. 326 (2015) 54-68.

[29] J.W. Li, P. Zhao, S.T. Liu. Appl. Catal. A.: General. 482 (2014) 363-369.

[30] S. Cao, H.Q. Wang, F.X. Yu, M.P. Shi, S. Chen, X.L. Weng, Y. Liu, Z.B. Wu. J. Colloid. Interf. Sci. 463 (2016) 233-241

[31] Y.M. Jiao, X. Chen, F. He, S.T. Liu. Chem. Eng. J. 372 (2019) 107-117.

[32] G.Y. Long, M.X. Chen, Y.J. Li, J.F. Ding, R.Z. Sun, Y.F. Zhou, X.Y. Huang, G.R. Han, W.R. Zhao. Chem. Eng. J. 360 (2019) 964-973.

[33] P. Yang, S.S. Yang, Z.N. Shi, Z.H. Meng, R.X. Zhou. Appl. Catal. B.: Environ. 162 (2015) 227-235.

[34] C. He, B.T. Xu, J.W. Shi, N.L. Qiao, Z.P. Hao, J.L. Zhao. Fuel. Process. Technol. 130 (2015) 179-187.

[35] Z. Zhang, J. Huang, H.Q. Xia, Q.G. Dai, Y.F. Gu, Y.J. Lao, X.Y. Wang. J. Catal. 360 (2018) 277-289.

[36] P. Yang, Z.H. Meng, S.S. Yang, Z.N. Shi, R.X. Zhou. J. Mol. Catal. A.: Chem. 393 (2014) 75-83.

[37] Q.G. Dai, L.L. Yin, S.X. Bai, W. Wang, X.Y. Wang, X.Q. Gong, G.Z. Lu. Appl. Catal. B.: Environ.182 (2016) 598-610.

[38] M. Wu, X.Y. Wang, Q.G. Dai, Y.X. Gu, D. Li. Catal. Today. 158 (2010) 336-342.

[39] X.L. Weng, Q.J. Meng, J.J. Liu, W.Y. Jiang, S. Pattisson, Z.B. Wu. Environ. Sci. Technol. 53 (2019) 884-893.

[40] C.B. He, K.L. Pan, M.B. Chang. Environ. Sci. Pollut. R. 25 (2018) 11584-11594.

[41] C.H. Zhang, C. Wang, W.C Zhan, Y.l. Guo, Y. Guo, G.Z. Lu, A. Baylet, A. GiroirFendler. Appl. Catal. B.: Environ. 129 (2013) 509-516.

[42] T. Cai, H. Huang, W.Deng, Q.G. Dai, W. Liu, X.Y. Wang. Appl. Catal. B.: Environ. 
166-167 (2015) 393-405.

[43] W. Li, H.Q. Ye, G.G. Liu, H.C. Ji, Y.H. Zhou, K. Han. Chinese. J. Catal. 39 (2018) 946-954.

[44] E. Ríos, S. Abarca, P. Daccarett, H. Nguyen Cong, D. Martel, .F. Marco, J.R. Gancedo, J.L. Gautier. Int. J. Hydrogen. Energy. 33 (2008) 4945-4954.

[45] Y. Wang, W. Deng, Y.F. Wang, L.M. Guo, T. Ishihara. Mol. Catal. 459 (2018) 6170.

[46] A. Elmhamdi, L. Pascual, K. Nahdi, A. Martínez-Arias. Appl. Catal. B.: Environ. 217 (2017) 1-11.

[47] Y.S. Wu, S. Shi, S.S. Yuan, T. Bai, S.T. Xing. Appl. Surf. Sci. 479 (2019) 12621269.

[48] P. Yang, S.S. Yang, Z.N. Shi, F. Tao, X.L. Guo, R.X. Zhou. Chem. Eng. J. 285 (2016) 544-553.

[49] C. He, Y.K. Yu, J.W. Shi, Q. Shen, J.S. Chen, H.X. Liu. Mater. Chem. Phys. 157 (2015) 87-100.

[50] A.D. Tang, L.Q. Hu, X.H. Yang, Y.R. Jia, Y. Zhang. Catal. Commun. 82 (2016) $41-45$.

[51] Y. Zhou, X.Y. Liu, K. Wang, J. Li, X.L. Zhang, X. Jin, X.Y. Tang, X.H. Zhu, R.S. Zhang, X. Jiang, B.D. Liu. Results. Phys. 12 (2019) 1893-1900.

[52] Q. Huang, H. Si, S.K. Yu, J.X. Wang, T. Tao, B. Yang, Y.X. Zhao, M.D. Chen. Environ. Technol. 41 (2020), 1664-1676.

[53] B.C. Liu, C.Y. Li, Y.F. Zhang, Y. Liu, W.T. Hu, Q. Wang, L. Han, J. Zhang. Appl. Catal. B.: Environ. 111-112 (2012) 467-475.

[54] X.Y. Wang, L. Ran, Y. Dai, Y.J. Lu, Q.G. Dai. J. Colloid. Interf. Sci. 426 (2014) 324-332.

\section{FIGURE LEGENDS}

Fig. 1. XRD patterns of $\mathrm{CuMn}_{2} \mathrm{O}_{4}$ catalysts: (A) $\mathrm{Cr}$, $\mathrm{Fe}$ and $\mathrm{Ce}$ doping, (B)

$\mathrm{CuCrMnO}_{4}, \mathrm{CuFe}_{0.25} \mathrm{Mn}_{1.75} \mathrm{O}_{4}$ and $\mathrm{CuCe}_{0.25} \mathrm{Mn}_{1.75} \mathrm{O}_{4}$ catalysts under different calcining temperature and time

Fig. 2. The pore-size distribution curves and $\mathrm{N}_{2}$ adsorption/desorption isotherms of $\mathrm{CuM}_{\mathrm{x}} \mathrm{Mn}_{2-\mathrm{x}} \mathrm{O}_{4}(\mathrm{M}=\mathrm{Cr}, \mathrm{Fe}$, and $\mathrm{Ce})$ catalysts

Fig. 3. SEM images of $\mathrm{CuM}_{\mathrm{x}} \mathrm{Mn}_{2-\mathrm{x}} \mathrm{O}_{4} / \mathrm{Crd}(\mathrm{M}=\mathrm{Cr}, \mathrm{Fe}$, and $\mathrm{Ce}$ ) catalysts (A: $\mathrm{CuCr}_{0.25} \mathrm{Mn}_{1.75} \mathrm{O}_{4} / \mathrm{Crd}$; B: $\mathrm{CuCrMnO}_{4} / \mathrm{Crd} ; \mathrm{C}: \mathrm{CuFe}_{0.25} \mathrm{Mn}_{1.75} \mathrm{O}_{4} / \mathrm{Crd}$; D: $\mathrm{CuFe}_{0.5} \mathrm{Mn}_{1.5} \mathrm{O}_{4} / \mathrm{Crd}$; E: $\left.\mathrm{CuCe}_{0.25} \mathrm{Mn}_{1.75} \mathrm{O}_{4} / \mathrm{Crd} ; \mathrm{F}: \mathrm{CuCeMnO}_{4} / \mathrm{Crd}\right)$

Fig. 4. TEM images of $\mathrm{CuM}_{\mathrm{x}} \mathrm{Mn}_{2-\mathrm{x}} \mathrm{O}_{4} / \mathrm{Crd}(\mathrm{M}=\mathrm{Cr}, \mathrm{Fe}$, and $\mathrm{Ce}$ ) catalysts (A: 
$\mathrm{CuCrMnO}_{4} / \mathrm{Crd} ; \mathrm{B}: \mathrm{CuFe}_{0.25} \mathrm{Mn}_{1.75} \mathrm{O}_{4} / \mathrm{Crd} ; \mathrm{C}$ and $\left.\mathrm{D}: \mathrm{CuCe}_{0.25} \mathrm{Mn}_{1.75} \mathrm{O}_{4} / \mathrm{Crd}\right)$

Fig. 5. The profiles of $\mathrm{CuM}_{0.5} \mathrm{Mn}_{1.5} \mathrm{O}_{4} / \mathrm{Crd}(\mathrm{M}=\mathrm{Cr}, \mathrm{Co}, \mathrm{Fe}, \mathrm{Ni}$, and Ce) catalysts (A) $\mathrm{H}_{2}$-TPR, and (B) $\mathrm{NH}_{3}-\mathrm{TPD}$

Fig. 6. (A) Ce 3d, (B) Cu 2p, (C) Mn 2p, (D) O 1s XPS spectra of $\mathrm{CuCe}_{\mathrm{x}} \mathrm{Mn}_{1-\mathrm{x}} \mathrm{O}_{4} / \mathrm{Crd}$ catalysts with different of $\mathrm{Ce} / \mathrm{Mn}$ molar ratios and calcining temperature

Fig. 7. Catalytic oxidation of $\mathrm{CB}$ over $\mathrm{CuMn}_{2} \mathrm{O}_{4}$ catalysts: (A) $\mathrm{Cr}, \mathrm{Co}, \mathrm{Mn}, \mathrm{Fe}, \mathrm{Ni}, \mathrm{Cu}$ and Ce doping; (B) $\mathrm{CuCr}_{\mathrm{x}} \mathrm{Mn}_{2-\mathrm{x}} \mathrm{O}_{4} / \mathrm{Crd}, \mathrm{CuFe}_{\mathrm{x}} \mathrm{Mn}_{2-\mathrm{x}} \mathrm{O}_{4} / \mathrm{Crd}$ and $\mathrm{CuCe}_{\mathrm{x}} \mathrm{Mn}_{2-\mathrm{x}} \mathrm{O}_{4} / \mathrm{Crd}$ with $\mathrm{x}=0.25,0.5$ and 1 .

Fig. 8. Catalytic oxidation of CB over (A): $\mathrm{CuCrMnO}_{4}$, (B): $\mathrm{CuFe}_{0.25} \mathrm{Mn}_{1.75} \mathrm{O}_{4}$, and (C): $\mathrm{CuCe}_{0.25} \mathrm{Mn}_{1.75} \mathrm{O}_{4}$ catalysts under different calcining temperature and time

Fig. 9. The stabilities of $\mathrm{CuCrMnO}_{4}, \mathrm{CuFe}_{0.25} \mathrm{Mn}_{1.75} \mathrm{O}_{4}$, and $\mathrm{CuCe}_{0.25} \mathrm{Mn}_{1.75} \mathrm{O}_{4}$ catalysts calcinated at $450^{\circ} \mathrm{C}$ and for $4 \mathrm{~h}$ for $\mathrm{CB}$ oxidation

Fig. 10. IR profiles of $\mathrm{CuM}_{\mathrm{x}} \mathrm{Mn}_{1-\mathrm{x}} \mathrm{O}_{4} / \mathrm{Crd}$ catalysts with the different conversion of $\mathrm{CB}\left(T_{20}, T_{50}\right.$ and $\left.T_{90}\right)$

Fig. 11. $\mathrm{CB}$ oxidation routes over $\mathrm{CuM}_{\mathrm{x}} \mathrm{Mn}_{1-\mathrm{x}} \mathrm{O}_{4} / \mathrm{Crd}$ 


\section{Table Captions and Footnotes}

\section{Table 1}

The structure and physical parameters of $\mathrm{CuM}_{\mathrm{x}} \mathrm{Mn}_{2-\mathrm{x}} \mathrm{O}_{4}(\mathrm{M}=\mathrm{Cr}, \mathrm{Fe}$, and Ce) catalysts with different $\mathrm{M} / \mathrm{Mn}$ molar ratios

\begin{tabular}{|c|c|c|c|c|c|c|}
\hline Samples & $\begin{array}{c}\text { S }_{\text {BET }} \\
\left(\mathbf{m}^{2} / \mathbf{g}\right)\end{array}$ & $\begin{array}{c}\text { Pore } \\
\text { volume } \\
\left(\mathrm{cm}^{3} / \mathrm{g}\right)\end{array}$ & $\begin{array}{c}\text { Average } \\
\text { pore size } \\
\quad(\mathbf{n m})\end{array}$ & $\begin{array}{c}\mathrm{Ce}^{3+} / \mathrm{Ce}^{4+} \\
(\%)\end{array}$ & $\begin{array}{c}\mathrm{Mn}^{4+} /\left(\mathrm{Mn}^{3+}+\right. \\
\left.\mathrm{Mn}^{2+}\right) \\
(\%)\end{array}$ & $\begin{array}{c}\mathbf{O}_{\text {latt }} / \mathbf{O}_{\mathrm{ads}} \\
(\%)\end{array}$ \\
\hline $\mathrm{CuCr}_{0.25} \mathrm{Mn}_{1.75} \mathrm{O}_{4} / \mathrm{Crd}$ & 12.4 & 0.055 & 16.8 & - & - & - \\
\hline $\mathrm{CuCr}_{0.5} \mathrm{Mn}_{1.5} \mathrm{O}_{4} / \mathrm{Crd}$ & 13.7 & 0.055 & 13.3 & - & - & - \\
\hline $\mathrm{CuCrMnO}_{4} / \mathrm{Crd}$ & 13.5 & 0.038 & 13.9 & - & - & - \\
\hline $\mathrm{CuFe}_{0.25} \mathrm{Mn}_{1.75} \mathrm{O}_{4} / \mathrm{Crd}$ & 13.9 & 0.054 & 11.8 & - & - & - \\
\hline $\mathrm{CuFe}_{0.5} \mathrm{Mn}_{1.5} \mathrm{O}_{4} / \mathrm{Crd}$ & 13.5 & 0.057 & 14.5 & - & - & - \\
\hline $\mathrm{CuFeMnO} / \mathrm{Crd}$ & 16.7 & 0.045 & 8.42 & - & - & - \\
\hline $\mathrm{CuCe}_{0.25} \mathrm{Mn}_{1.75} \mathrm{O}_{4} / \mathrm{Crd}$ & 21.1 & 0.106 & 13.7 & 31.0 & 72.6 & 32.0 \\
\hline $\mathrm{CuCe}_{0.5} \mathrm{Mn}_{1.5} \mathrm{O}_{4} / \mathrm{Crd}$ & 50.8 & 0.326 & 19.4 & 25.8 & 74.6 & 29.5 \\
\hline $\mathrm{CuCenO}_{4} / \mathrm{Crd}$ & 29.9 & 0.163 & 17.8 & 26.4 & 69.2 & 29.5 \\
\hline
\end{tabular}


Fig. 1
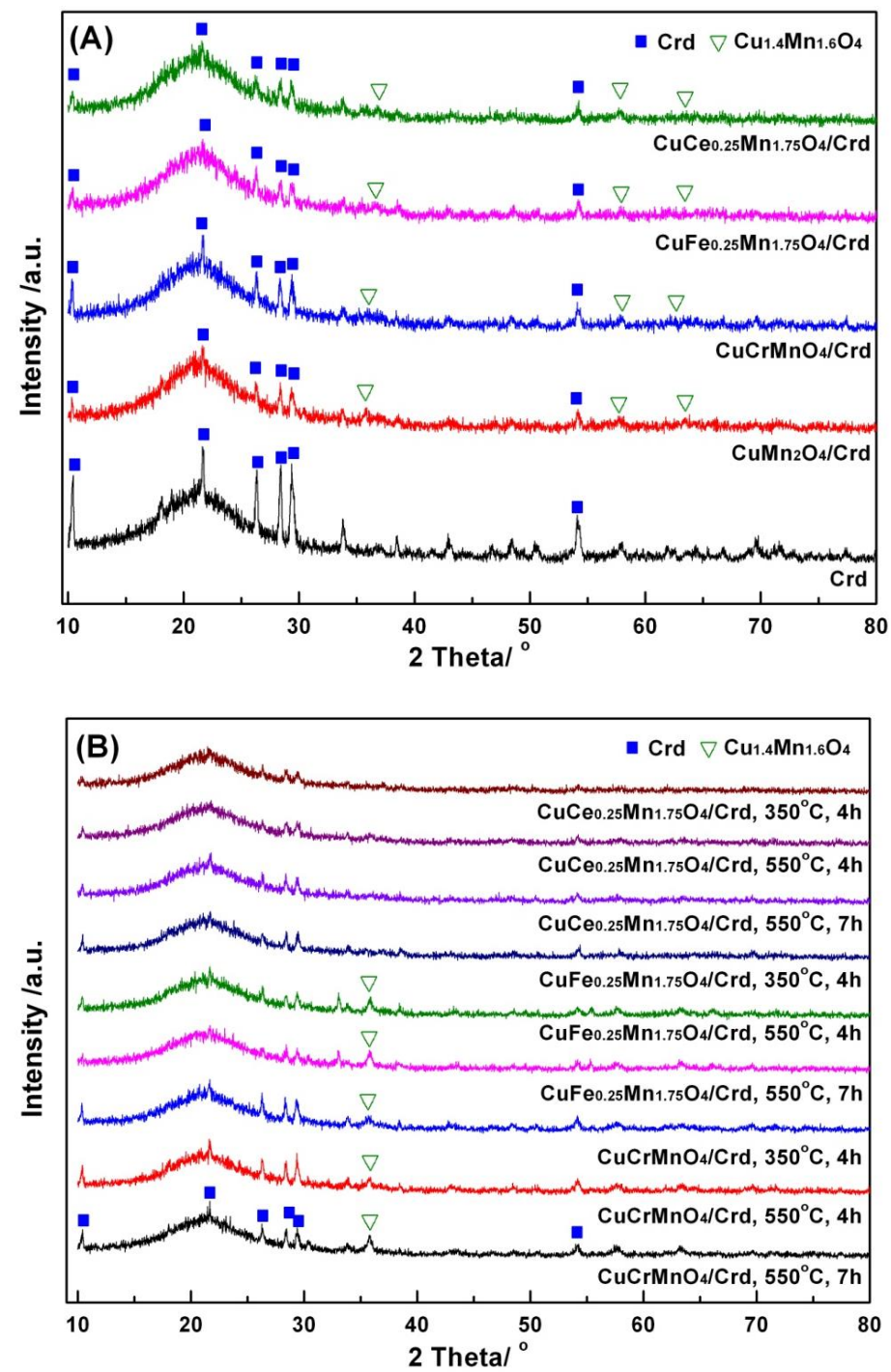
Fig. 2

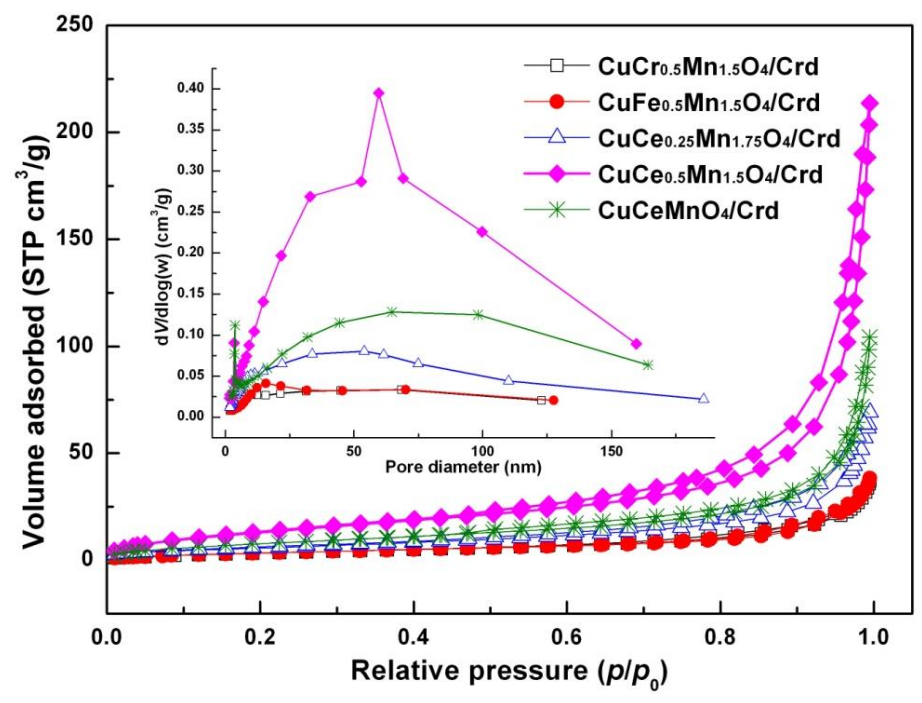


Fig. 3
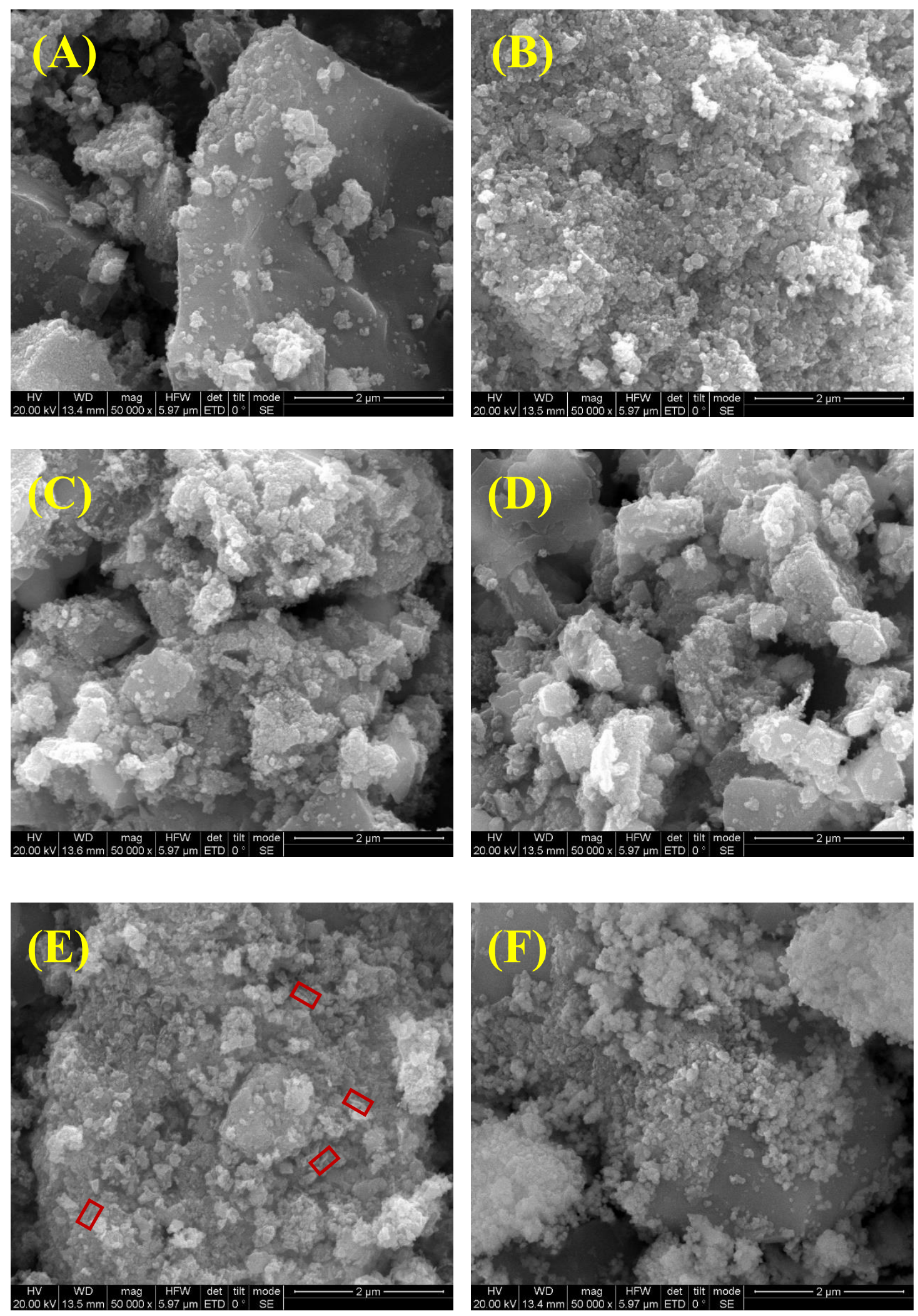
Fig. 4
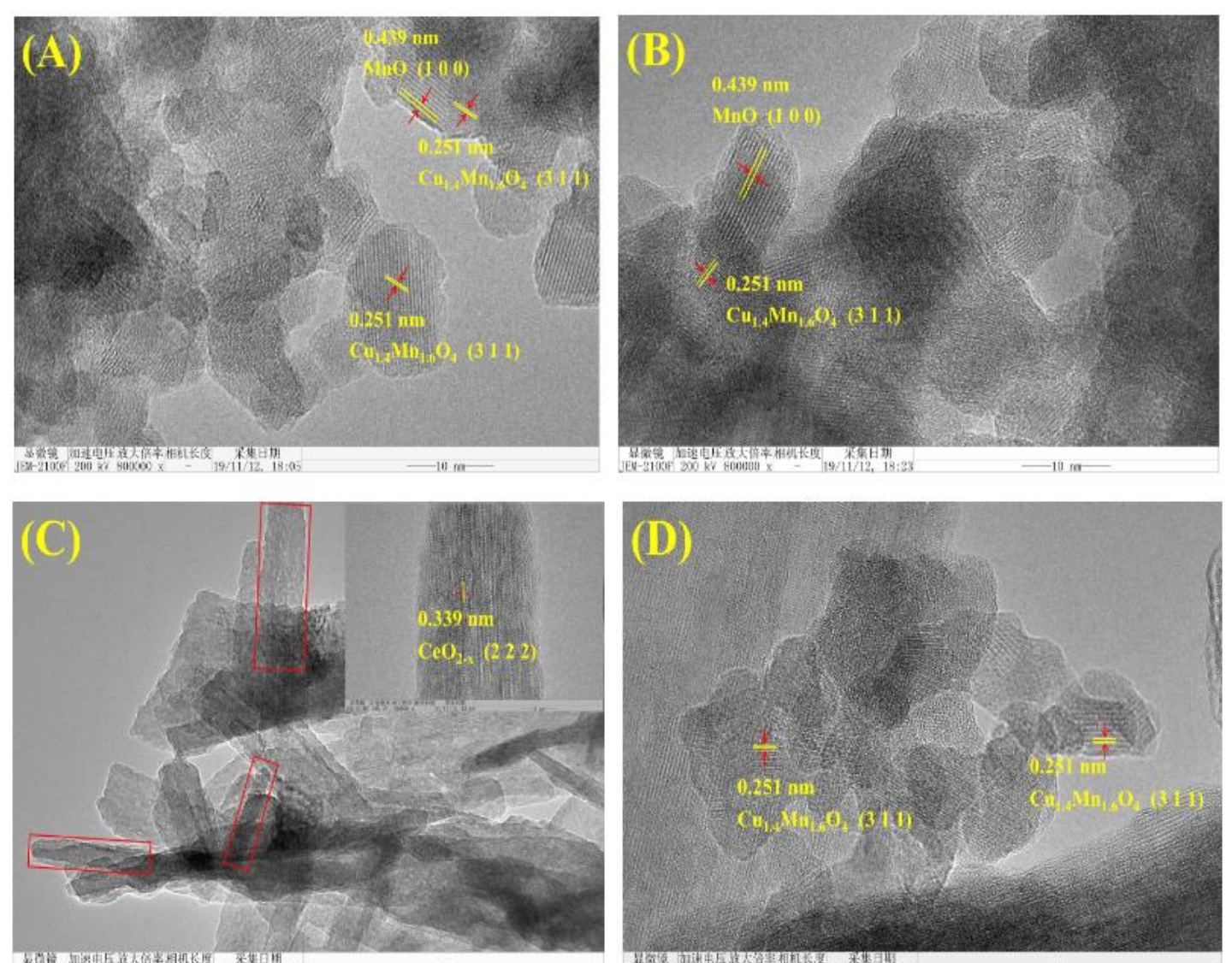

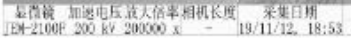

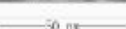

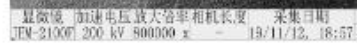


Fig. 5
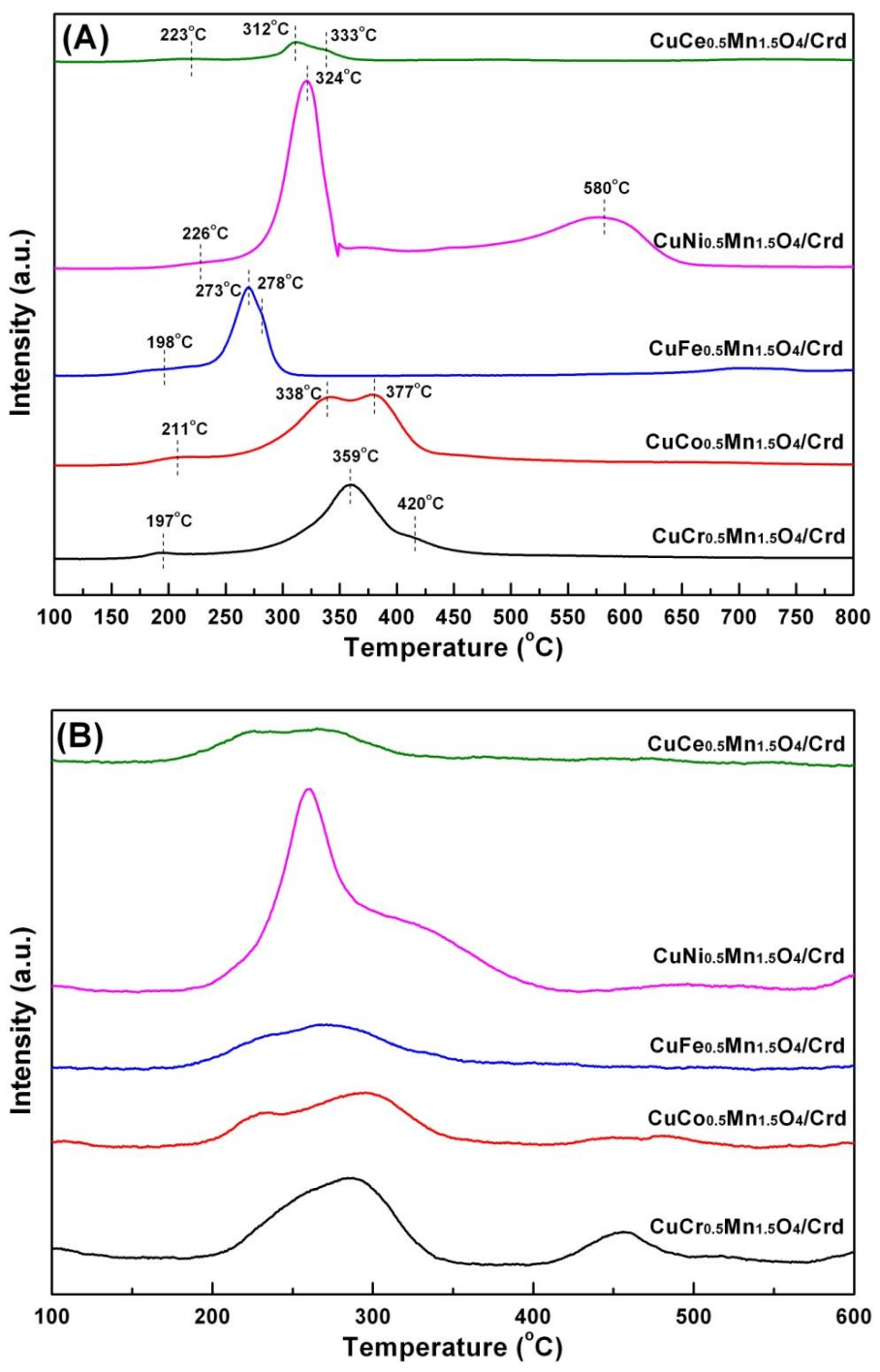
Fig. 6
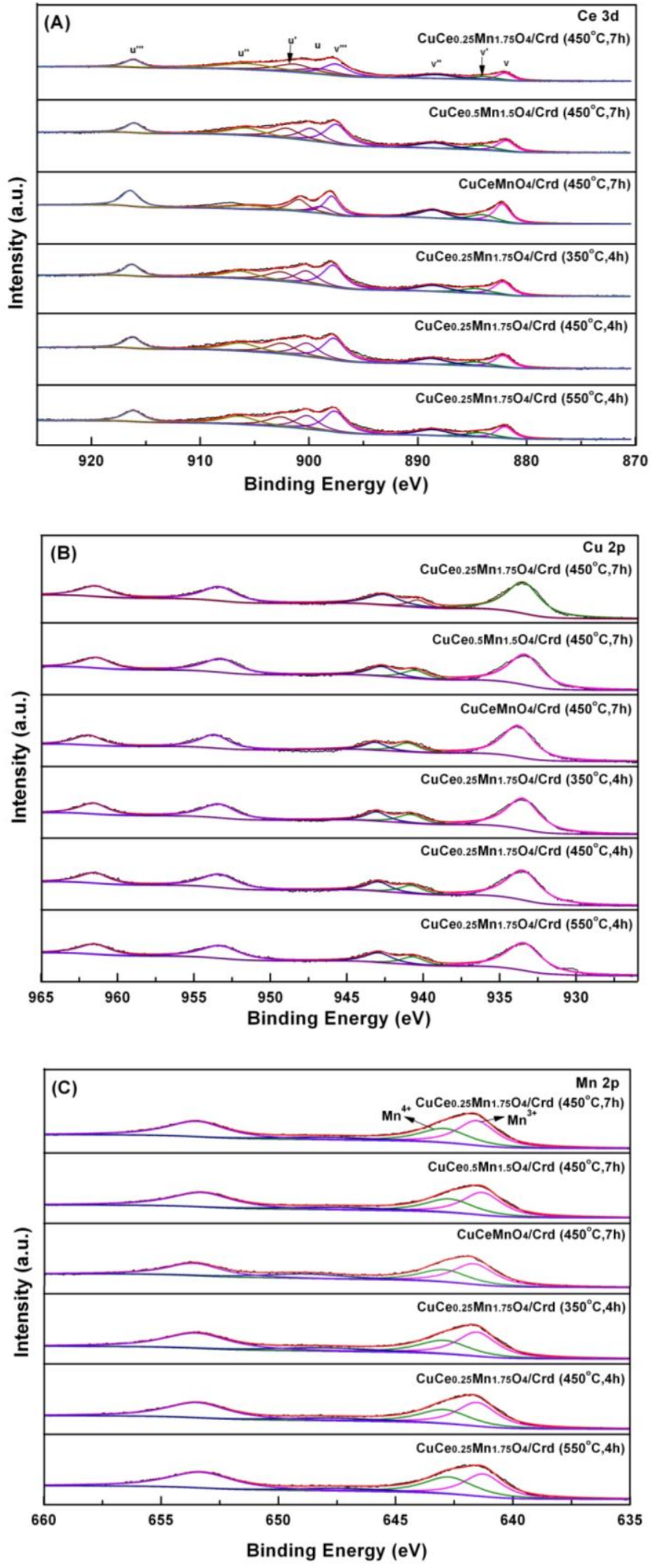


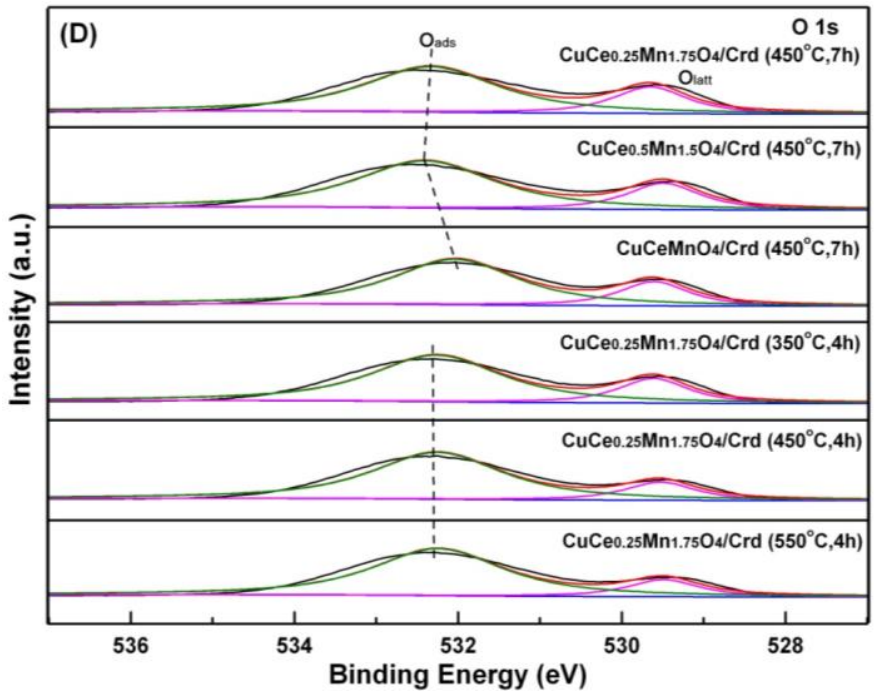


Fig. 7
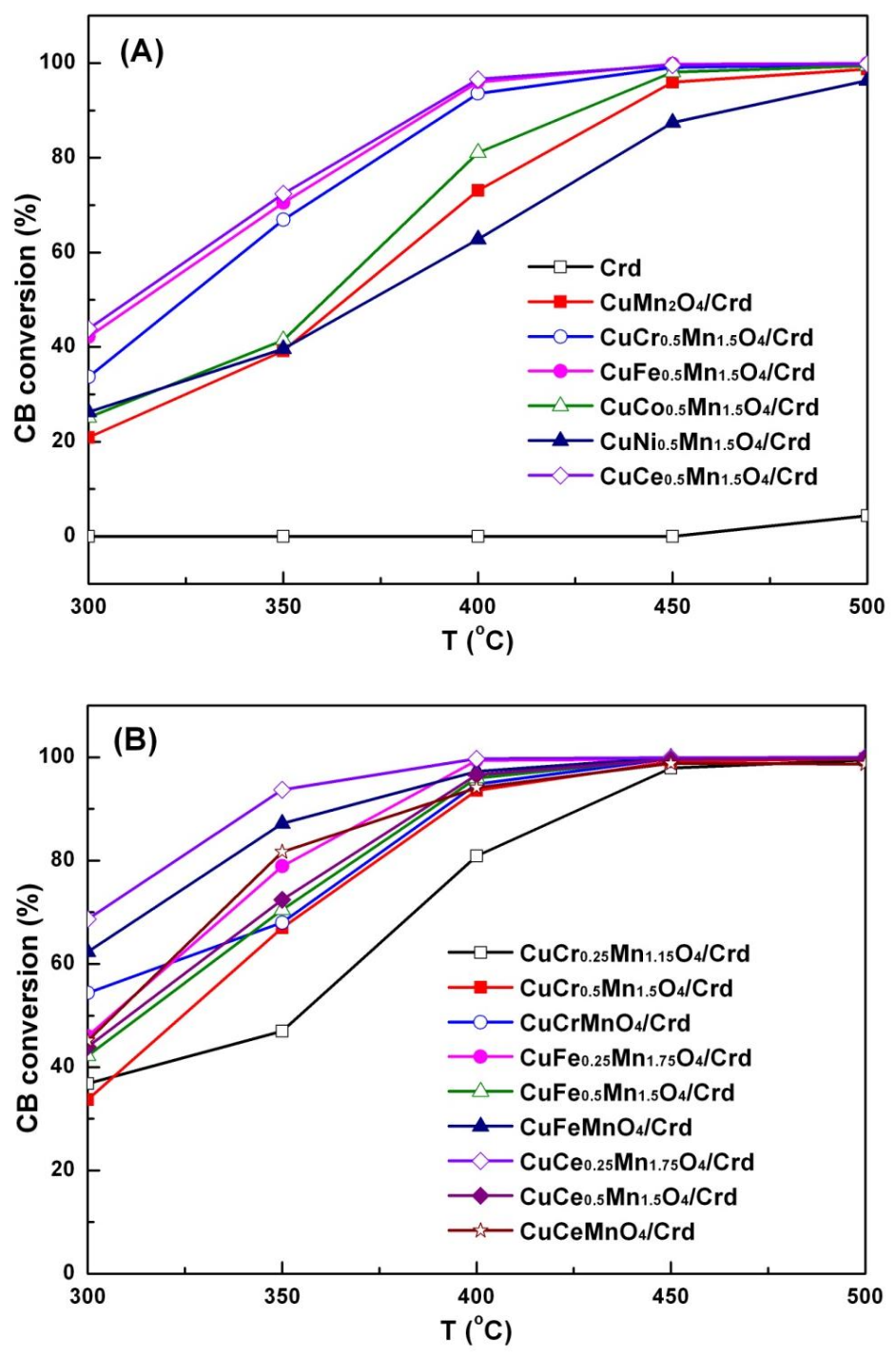
Fig. 8
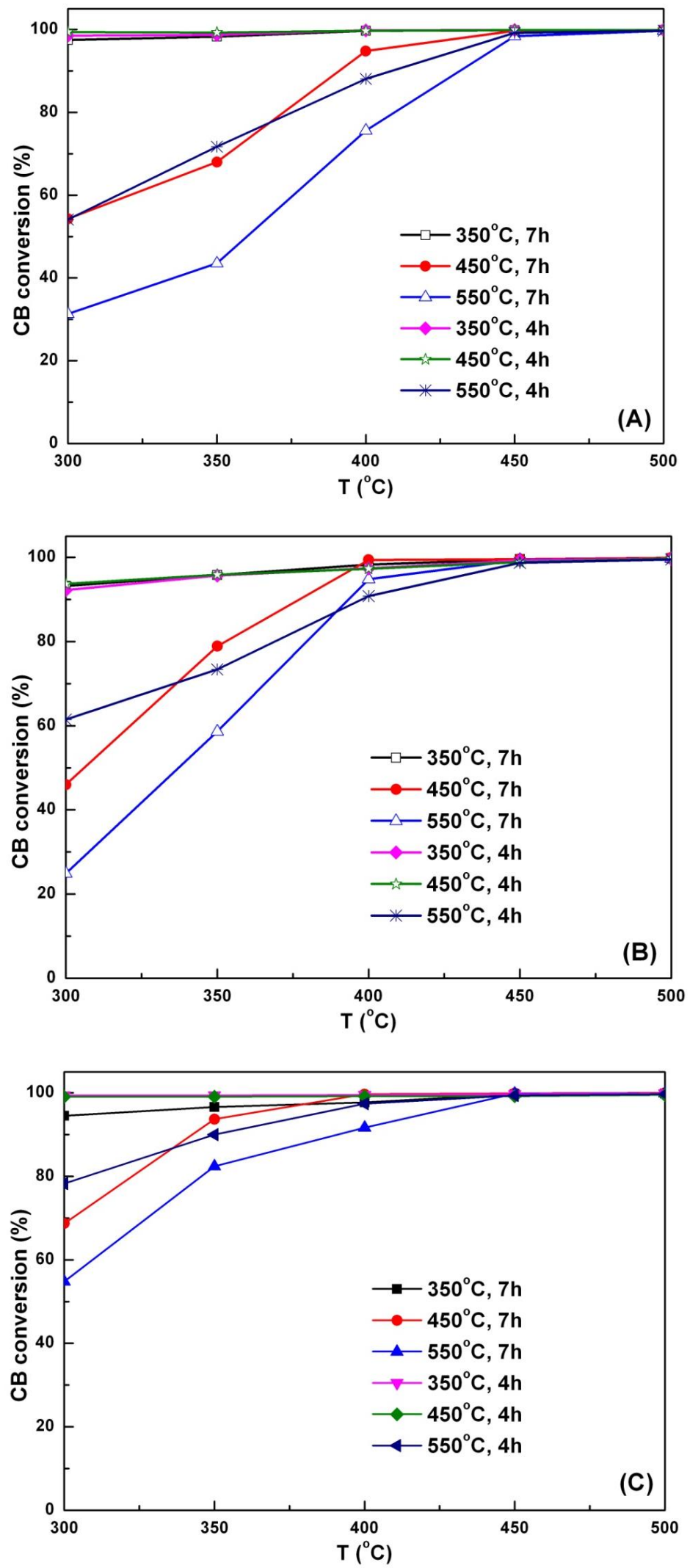
Fig.9

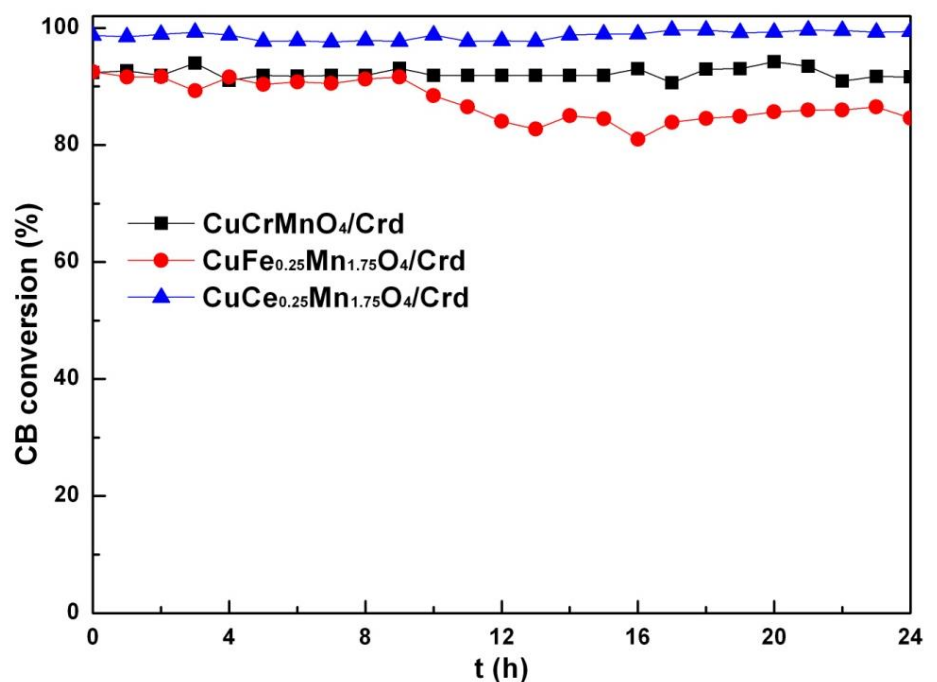


Fig. 10

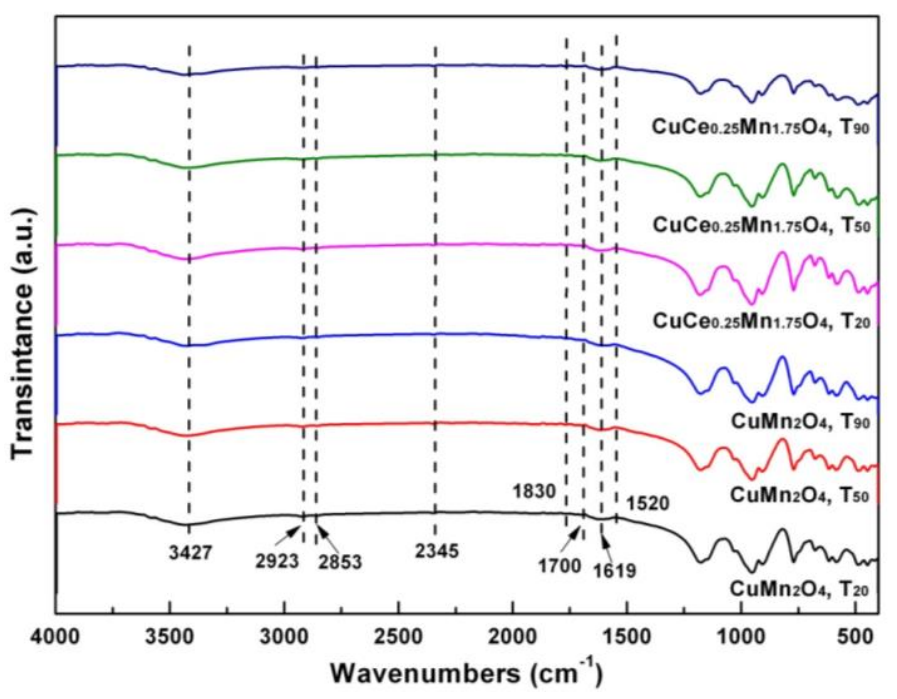


Fig. 11

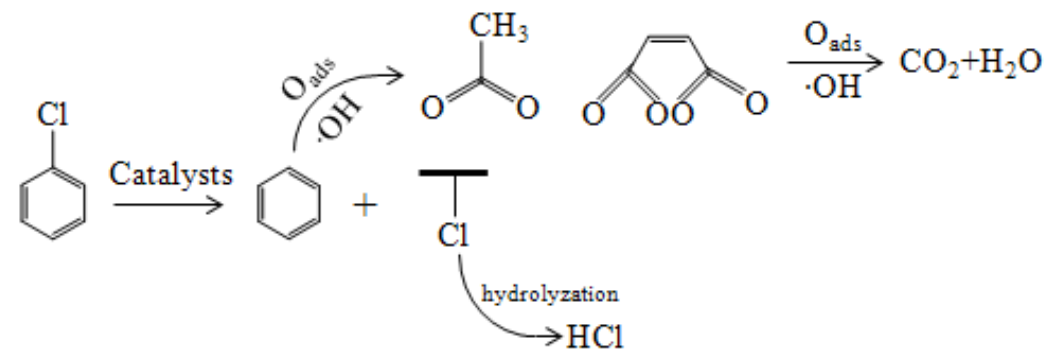

